How to Get the Snowball Rolling and Extend the Franchise:

Voting on the Great Reform Act of 1832

Toke S. Aidt and Raphaël Franck

August 2008

CWPE 0832 


\title{
How to Get the Snowball Rolling and Extend the Franchise: Voting on the Great Reform Act of $1832^{*}$
}

\author{
Toke S. Aidt ${ }^{\mathrm{a}}$ \\ Faculty of Economics and Jesus College, University of Cambridge \\ Raphaël Franck ${ }^{\mathrm{b}}$ \\ Department of Economics, Bar Ilan University
}

\begin{abstract}
This paper suggests a new approach to analyze the causes of franchise extension. Based on a new dataset, it provides a detailed econometric study of the Great Reform Act of 1832 in the United Kingdom. The econometric analysis yields four main results. First, modernization theory only receives mixed support. Second, the reform enjoyed some measure of popular support. Third, the threat of revolution had an asymmetric impact on the voting behavior of the pro-reform Whigs and the anti-reform Tories. While the threat might have convinced reluctant reformers among the Whig politicians - and among their patrons - to support the bill, it seems to have hardened the resistance to reform among the Tories. Fourth, ideology played a critical role. However, it also appears that self-interest and political expedience explained the votes of many Members of Parliament.
\end{abstract}

Keywords: Franchise extension; democratization; The Great Reform Act.

JEL Classification: D7, H1.

\footnotetext{
${ }^{*}$ We thank Hans Pitlik and participants at the 2008 EPCS meeting in Jena for helpful comments. The usual disclaimer applies.

a Faculty of Economics, Austin Robinson Building, Sidgwick Avenue, CB39DD Cambridge, U.K. Email: tsa23@econ.cam.ac.uk.

${ }^{\mathrm{b}}$ Bar Ilan University, Department of Economics, 52900 Ramat Gan, Israel. Email: franckr@mail.biu.ac.il.
} 


\section{Introduction}

To this day, the passing in 1832 by the British Parliament of a bill, which subsequently became known as the Great Reform Act, is seen as a watershed. The immediate consequences of this reform were to redistribute parliamentary seats from the small "rotten boroughs"1 to the large and fast growing industrial cities, as well as to extend the franchise to "respectable" segments of the middle class. But in the long run, the Great Reform Act was the pivotal event that got the snowball rolling: it was the first of five major reforms that gradually transformed the political system in the United Kingdom. In the 1830 general election, no more than three per cent of the adult male population could cast their vote while the bulk of the 658 Members of Parliament (MPs) were returned in uncontested elections. Less than 100 years later, in 1928, all men and women aged 21 and above could vote in contested elections. In the intertwining years, the franchise had gradually been extended by the Second Reform Act of 1867, the Third Reform Act of 1884, and the Fourth Reform Act of 1918. In addition, the secret ballot had been introduced in 1872, plural votes discontinued, and a uniform system of districting adopted (see among others Machin, 2001).

Broadly speaking, the historical narrative suggests two rationales for the success of the Great Reform Act. $^{2}$ One emphasizes extra-parliamentarian pressures and points to evidence such as the riots in several towns in the autumn of 1831, talks of armed uprising, and the flood of petitions to Parliament from all parts of the country in support of reform. Another emphasizes changes in the balance of power within Parliament. These

\footnotetext{
${ }^{1}$ Rotten boroughs were also known as "nomination" or "pocket" boroughs.

${ }^{2}$ See Brock (1973) and Cannon (1973) among others. See also Evans (2000) for a concise exposition.
} 
changes included the fall of the anti-reform Tory government in 1830 which allowed a pro-reform Whig government to take office for the first time since 1806.

But beyond the historical narrative, economists and political scientists alike have developed formal theories that seek to explain the willingness of ruling elites to share power with groups whose goals they may oppose. They have emphasized modernization theory, i.e., the role of economic growth and social progress (Moore, 1966), the role of ideology (Tilly, 2004), mass conscription armies (Janowitz, 1976), or the broader context of constitutional bargaining (Congleton, 2004, 2007). Some prominent scholars, e.g., Justman and Gradstein (1999), Acemoglu and Robinson (2000; 2005) and Boix (2003), have argued that external pressures, which are often conceptualized as a threat of revolution, forced the elites to share power. Seen in this perspective, granting voting rights to previously disenfranchised groups was a lesser evil for the ruling elite. Others have suggested that the extension of the suffrage was a consequence of economic changes that made democracy more profitable for the ruling elite. This might be the case if property rights are better protected under democracy (Gradstein, 2007), if democracy enhances human capital accumulation (Bourguignon and Verdier, 2000) or if a significant fraction of the elite can benefit from greater provision of public services under democratic governments (Lizzeri and Persico, 2004).

All of these theories offer convincing interpretations of specific historical episodes and can be supported by detailed historical case studies. Some of them have also been subjected to econometric testing. ${ }^{3}$ These tests, which focus on the consequences of

\footnotetext{
${ }^{3}$ See among others Meltzer and Richard (1983), Hettich and Winer (1988), Lindert (1994), Husted and Kenny (1997), Kenny and Lott (1999), Persson and Tabellini (2003), Aidt et al. (2006) and Aidt and Jensen (2008a, 2008b).
} 
suffrage reform rather than on its underlying causes, employ cross-country or cross-state variations in the franchise rules to identify the effects of democratization.

This paper suggests a new approach to the study of franchise extension. Our approach is to investigate the underlying causes of democratization by studying the votes of the politicians who adopt suffrage reforms. This allows us to test the relevance of competing theories of democratization in new ways. ${ }^{4}$ The Great Reform Act of 1832 is well-suited for such an empirical approach because it was debated and voted on under the rules of the Unreformed Parliament. These rules had not been changed for almost 200 years prior to the reform and can therefore be taken as exogenous. ${ }^{5}$ Moreover, the Unreformed Parliament exhibited a very rich and varied set of institutions that allows us to construct new tests of four prominent theories of franchise extension. We can thus assess the causal role played by ideology, the threat of a revolution, and economic factors such as the rise of a middle class and economic prosperity, in the adoption of the Great Reform Act. For this purpose, we assembled a new dataset from a combination of primary and secondary sources that provides detailed information on the characteristics of each parliamentary constituency in England and Wales, as well as on the elected MPs. ${ }^{6}$

The econometric analysis yields four main results. First, modernization theory only receives mixed support. On the one hand, we find that economic prosperity in a

\footnotetext{
${ }^{4}$ Schonhardt-Bailey (1998) adopts a similar approach in her study of industrial and agricultural interests in the German Parliament during the nineteenth-century. See also Schonhardt-Bailey (2006) on the repeal of the Corn Laws.

${ }^{5}$ The challenge of finding exogenous variations in institutions has received substantial attention in some recent studies on democratization. On this issue, see, for instance, Acemoglu et al. (2001).

${ }^{6}$ As a caveat, it must be noted that the lack of information about the characteristics of the Scottish and Irish boroughs and counties compels us to focus on the MPs elected in England and Wales only. Out of the 658 MPs returned to Parliament in 1830 and 1831, 513 were elected in England and Wales.
} 
constituency increased, rather than decreased, the likelihood that an anti-reform MP was returned to Parliament. On the other hand, we do find some evidence that the economic changes that created more cohesive working and middle classes spurred the reform process. Second, the reform enjoyed some measure of popular support. In particular, we find that pro-reform MPs were more likely to be elected in constituencies with relatively large electorates and contested elections. Third, the threat of revolution had an asymmetric impact on the voting behavior of the pro-reform Whigs and the anti-reform Tories. While the threat might have convinced reluctant reformers among the Whig MPs - and among their patrons - to support the bill, it seems to have hardened the resistance to reform among the Tories. Fourth, ideology played a critical role. However, we also find evidence that self-interest and political expedience explained the votes of many MPs.

The rest of the paper is organized as follows. Section 2 discusses the political system in the United Kingdom under the Unreformed Parliament and provides an overview of the events that led to the Great Reform Act. Section 3 sets out our hypotheses and econometric strategy. Section 4 discusses the empirical results. Section 5 concludes. The Appendix provides some additional estimations and outlines the content of the Great Reform Act.

\section{The Unreformed Parliament and the Great Reform Act: Data and Historical Background}

In 1830 , the electoral rules of the Unreformed Parliament were still virtually the same as in the past centuries. Despite the economic transformations caused by the industrial revolution, there had neither been any substantial redistribution of seats since the seventeenth century, nor any notable extension of the franchise. This had already 
created by the end of the eighteenth century a large imbalance between the old and new population centers. The South of England, particularly Cornwall, was over-represented, while the large industrial cities in the Midlands and the North, such as Birmingham, Leeds and Manchester, did not elect any MP.

The politics of the Unreformed Parliament was very different from that of modern parliamentary democracies. Firstly, the franchise rules, which governed who could vote, were not uniform throughout the country. Some franchises allowed for large electorates while others did not, and the vast majority of the adult population was disenfranchised. Voting was not secret, and polling lasted several days. Secondly, patronage was a major feature of the Unreformed Parliament: aristocrats or commoners, called patrons, controlled the electorate, either fully or partially, in many boroughs and counties. As a result, most elections were not contested on a regular basis (Cannon, 1973, Appendix 3). Thirdly, by modern standards, elections were highly corrupt. Candidates willing to spend money could always buy a seat, and not only in the rotten boroughs, which could be bought right out, such as Gatton which was sold for $£ 180,000$ in the summer of 1830 . Indeed, elections were costly because voters expected candidates to organize banquets at the time of the polls and to compensate them for travel expenses. This practice, called "treating", cost more than $£ 100,000$ to the candidates running in Liverpool in 1830 . It was not unusual that candidates spend at least $£ 20,000$ to finance their campaigns to win an open seat in a borough. ${ }^{7}$

In the remainder of this section, we describe how the Unreformed Parliament worked and present the data that we employ in the econometric analysis. We also provide

\footnotetext{
${ }^{7}$ This should be compared to the annual income of the 200 richest families. It was about $£ 50,000$ per annum. The income of the gentry was less than $£ 2,000$ per annum.
} 
a brief historical overview of the events that culminated in the adoption of the Great Reform Act. Table A1 in the Appendix presents descriptive statistics.

\subsection{Politicians and political parties in the Unreformed Parliament}

The 658 seats of the Unreformed Parliament were divided between 188 county seats, 465 borough seats and five university seats. ${ }^{8}$ England and Wales respectively returned 489 and 24 MPs while Scotland and Ireland elected the remainder. Due to data limitations, our econometric analysis is restricted to the MPs elected in England and Wales. Therefore, most of the descriptive evidence we present below only relates to this group of MPs.

The MPs received no salary and were subject to a high property qualification. This effectively prevented individuals from the lower classes from running in the elections. Between 1780 and 1830, about one-fifth of all MPs were the sons of peers, while 200 MPs could be said to represent the gentry (Whitfield, 2001, p. 33). The data that we collected on the occupations and the social background of the MPs elected in 1830 and in 1831 illustrate the aristocratic nature of the Unreformed Parliament very clearly. ${ }^{9}$ The MPs were army officers, lawyers or jurists, bankers, industry owners, merchants, landowners or "dynasty heirs", i.e., the MPs who were immediately returned to Parliament when they finished their education and/or reached majority. ${ }^{10}$ Many MPs

\footnotetext{
${ }^{8}$ The universities of Cambridge, Dublin and Oxford were self-governing bodies that returned MPs on a franchise that granted all graduates the right to vote. Cambridge and Oxford returned two MPs while the University of Dublin returned only one MP.

${ }^{9}$ The data are collected from Judd (1955), Namier and Brooke (1964), Porrit and Porrit (1903), Stookes Smith (1973), Thorne (1986), and various editions of Dod's Parliamentary Companions.

${ }^{10}$ It must be noted that the categories are not mutually exclusive and many MPs are therefore recorded in more than one category, e.g., army officer and landowner. In our estimations, we use landowners as the control group.
} 
also had a relative who previously sat in Parliament. The distribution of the MPs' occupations in the 1830 and 1831 Parliaments, respectively, is shown in Figure 1. We notice a small drop in the representation of landowners and in "dynasty heirs" between the 1830 and 1831 Parliaments, but it is clear that both Parliaments were dominated by the landowning interest.

[Figure 1 here]

Although political parties in the modern sense did not exist in the Unreformed Parliament, it is possible to identify two broad groupings of MPs: the Tories and the Whigs. The Tories defended the prerogatives of the monarch and the status of the Church of England. They supported the governments appointed by the British kings from 1808 to 1830 and were hostile to parliamentary reform. They feared the dangerous precedent that even a modest reform would set, but their opposition was also motivated by self-interest since many Tories were returned in rotten boroughs.

The Whigs were in favor of shifting the balance of power from the King to the Commons. They were also supportive of the demand of nonconformists and Catholics for greater religious freedom and civil equality. The Whigs were more inclined to parliamentary reform than the Tories. Both parties, however, held the strong belief that society was best governed by the landowning classes, and that the other classes should be kept away from power. Many Whigs, including Lord Grey - the Prime Minister who eventually oversaw the reform of Parliament - were reluctant reformers (Cannon, 1973, chapter 8$).{ }^{11}$ Neither the Whigs nor the Tories supported universal male suffrage. Such

\footnotetext{
${ }^{11}$ An exception was Lord John Russell, who was a keen supporter of reform and was behind several reform attempts in the early 1820 s, including the disenfranchisement of Grampound.
} 
far-reaching ideas were reserved for the third "party", the Radicals, who were only represented in the 1830 Parliament by six MPs. ${ }^{12}$

The 1830 Parliament was dominated by the Tories who held 63 per cent of the English and Welsh seats. After the 1831 election, which was fought almost exclusively on the reform question, the majority had shifted with 55 per cent of the seats now being held by the Whigs.

\subsection{The economic, administrative and political characteristics of the English and Welsh constituencies}

The constituencies where the MPs of the Unreformed Parliament were elected did not only differ by their economic circumstances, but also by their governance structure and franchise rules. Differences in institutional arrangements and economic circumstances affected the ease with which patrons could exercise influence.

\subsubsection{The economic circumstances of the constituencies}

We use two sources of information to assess the economic circumstances of the constituencies. Firstly, the 1831 Census of Great Britain provides information that can be used to reckon the occupational structure of each constituency in England and Wales. These data include the shares of agricultural and industrial workers, landowners, artisans, servants, professionals, e.g., lawyers and doctors, in the workforce of each constituency. ${ }^{13}$

\footnotetext{
12 Some Radicals even opposed the unsuccessful attempt by Lord Russell to give representation to some large British towns in February 1830 because they considered that the measures were not extensive enough. 13 The census and parliamentary districts do not overlap exactly. This should be kept in mind when studying the descriptive statistics but does not limit the relevance of these data for our estimations. The reason is that we use these data to assess the impact of economic circumstances in the elections, not to infer how individuals voters voted (see King, 1997). In any case, as we discuss below, most individuals did not have the right to vote under the rules of the Unreformed Parliament.
} 
As one would expect, the vast majority of the adult population were employed as unskilled workers or servants. Only a small fraction belonged to the landowning class while professionals made up about 14 per cent of the workforce.

Secondly, we use the information provided by Philbin (1965) to single out the constituencies that were thriving and those that underwent a marked economic decline at the time of the Great Reform Act. ${ }^{14}$ Measured in this way, 91 constituencies had a thriving economy in 1830 while 102 were undergoing a notable decline.

\subsubsection{The franchise rules and the governance structure of the constituencies}

As mentioned above, the franchise rules of the Unreformed Parliament were complex and not uniform. In the English and Welsh counties, the franchise rules allowed men to vote if they owned freehold land or property worth at least 40 shillings a year. The 40-shilling qualification had not been indexed since its introduction in 1430 . Thus, by 1830 , it had become a very modest qualification which allowed many relatively poor tenant farmers to vote. However, they did not have the financial resources to stand up to their landlords, who would often tell them how to vote. ${ }^{15}$

Unlike the counties which had a uniform franchise, there were six franchise types in the English and Welsh boroughs, as documented in Table 1. The Table shows the

\footnotetext{
${ }^{14}$ For most constituencies, no information is recorded. We assume that these constituencies followed the general (downward) economic trend and they make up our control group in the statistical analysis.

${ }^{15}$ The franchise rules in Ireland and Scotland were different from those in England and Wales. The rules governing the election of the 100 Irish MPs were designed to ensure the exclusion of Catholics. In fact, Catholics could not serve as MPs before the 1829 Catholic Emancipation Act. In Scotland, the 45 MPs were elected in close boroughs in which the burgh corporations controlled the elections via a system of indirect election or in counties with very small electorates. While money was the source of corruption in England, patronage was the dominant means of influence in Scotland, giving the government of the day a large degree of control over the returns.
} 
distribution of boroughs across the six franchise types and the approximate size of the electorate in 1830. The rules in the corporation, freeholder and burgage boroughs typically resulted in very small electorates. In contrast, boroughs with scot and lot, potwalloper or freeman franchise had relatively large electorates and usually held contested elections.

There were, however, many exceptions, as the size of the electorate varied, not only between the different franchise types, but also within a given type. For example, some of the freeman boroughs had electorates totaling more than 5000 voters, e.g., Bristol, while others had fewer than 50, e.g., Hastings. Moreover, in Carlisle, the Earl of Lonsdale secured the freeman status for 14,000 coal miners, whom he employed so that they could vote for his candidates in the elections.

[Table 1 here]

The governance structure of a constituency, which determined who administered the borough or county on a day-to-day basis, was another institutional feature shaping its politics. Four governance types can be distinguished: municipal corporations, representative boroughs or boroughs with officials appointed at the court leet of the lord of the manor, universities and counties. As many as 164 out of the 214 English and all the Welsh boroughs had a municipal corporation, but the remaining 50 did not have any independent administrative structure. In these boroughs, patrons could be very influential. In contrast, in boroughs with a municipal corporation, which consisted of a mayor, aldermen, burgesses and other officials, there was a body that, in principle, could curb the influence of local patrons. For instance, Bodmin, Bath and Bury St Edmunds were 
relative free from aristocratic influence, despite small electorates. However, many of the smaller corporations depended on the financial support of local patrons.

\subsubsection{Patrons and the openness of elections}

It is useful to think of the Unreformed Parliament along a line that measures the degree of aristocratic influence on the elections of MPs. At one end, there were the MPs for the most populous and independent counties, e.g., Yorkshire, and the two members for Westminster, a borough with a large and independent electorate known for its radicalism. At the other end, there were the MPs for the rotten boroughs, such as Gatton and Old Sarum, which were effectively owned by private individuals who nominated the MPs. In addition, the Treasury, i.e., the government of the day, also controlled the returns of several constituencies, usually through employment as in the docks of Chatham. As such, in 1827, John Wilson Croker, who was then Secretary to the Admiralty, estimated that as many as 276 seats were held by direct nomination (see Croker, 1884). As a rule of thumb, one can assume that the influence of patrons increases as one moves to the left across the columns and down across the rows of Table 1, towards the smaller boroughs.

We use two measures to capture the influence of patrons in the constituencies. The first measure is an index that directly assesses the patrons' influence and is based on the qualitative information provided by Philbin (1965). We divide the constituencies into five categories. We consider that there was a high degree of aristocratic influence in a constituency when (i) a single patron controlled the governing body of the borough or had ownership of the property to which voting rights were attached or when (ii) a single patron effectively nominated the MPs or a sharing arrangement between multiple patrons was in place, with each of the patrons nominating one MP. We consider that patrons had 
an intermediate degree of influence when Philbin (1965) records that one, but not all the seats were controlled by a patron, or records evidence of rivalry between at least two patrons. We also single out the Treasury boroughs, which were under the patronage of the government, as well as the constituencies that are explicitly characterized as independent constituencies by Philbin (1965). Finally, we assume that there was a low degree of aristocratic influence when Philbin (1965) does not provide any specific information. ${ }^{16}$

Table 2 shows that the majority of the English and Welsh constituencies were under some form of aristocratic or governmental influence in 1830. In view of our measure, it even appears that patrons directly controlled about 36 per cent of the boroughs. The counties were theoretically more independent than the boroughs because of their large electorates. Nevertheless, the landowning aristocracy also controlled the majority of county seats.

\section{[Table 2 here]}

Our second measure of aristocratic influence is the extent to which the nine elections held between 1802 and 1831 were contested. In the vast majority of boroughs, less than half of the elections were contested, as Figure 2 shows. In a quarter of the boroughs, there was no contested election during the 30 years which preceded the Reform. Only in four boroughs - Beverley, Liverpool, Boston and Maidstone - were all nine elections contested between 1802 and 1831. Although county elections could be particularly expensive, elections did take place in at least 22 of the 40 English counties

\footnotetext{
${ }^{16}$ Although this is likely to be an indication that the degree of patronage was low in these constituencies, this category might also contain constituencies for which information is simply missing irrespective of the "true" level of aristocratic influence. This last category is used in the statistical analysis as the control group.
} 
during the period, while we know for a fact that no contest took place in eight of them. In Wales, contested elections were more common, with only three boroughs being entirely uncontested throughout the period (Philbin, 1965). For the purpose of the statistical analysis, we classify the constituencies into two categories: those with at least one contested election between 1802 and 1831 (“Contested Seat”) and those without any contested elections (“Uncontested Seat”). ${ }^{17}$

[Figure 2 here]

\subsection{Parliamentary reform and the Great Reform Act: some historical background}

In this section, we provide some historical background on the parliamentary reform movement in Great Britain and the events that led to the adoption of the Great Reform Act.

\subsubsection{The support for parliamentary reform before 1830}

The question of parliamentary reform had first arisen in the second half of the eighteenth century and resurfaced after the Napoleonic wars. Spurred on by post war economic distress, a reform movement outside Parliament led by the Radicals pushed for wide ranging reforms that included the secret ballot, yearly Parliaments and universal male suffrage. They campaigned against a system that was widely perceived as being corrupt and unrepresentative. ${ }^{18}$ But support amongst working men died out as trade

\footnotetext{
${ }^{17}$ For some Welsh boroughs, we do not have definite information on the number of contested elections. We use these constituencies as the control group in the statistical analysis.

${ }^{18}$ O'Gorman (1989) challenged the traditional interpretation of the Unreformed Parliament as being corrupt and argued using detailed information from the poll books that the old system was relatively representative and participatory and less corrupt than it is usually given credit for. As pointed out by Pearce and Stearn (1994, page 23), this revisionist position builds on the study of a few boroughs which held regular elections. Thus, it is not clear if the picture of "vitality" rather than "corruption" can be generalized.
} 
conditions improved. Thus, the Tory government of Lord Liverpool was both able and willing to severely repress the reform movement (Brock, 1973, chapter 1). By the late $1820 \mathrm{~s}$, parliamentary reform seemed an unlikely prospect. Three events, however, contributed to putting reform back on the agenda.

First, Lord Liverpool, who had held together the Tory party since 1812, had a stroke in 1827 , and was replaced first by Canning, then by Goderich and finally by the Duke of Wellington. This succession of leaders substantially weakened the antireformers. Second, after the 1828 by-election in the Irish county of Clare which the Catholic lawyer Daniel O'Connell won, Wellington's government was in a quandary: it faced a rebellion in Ireland if O'Connell was not allowed to take up his seat, or a split in the Tory party if he was, as this would make Catholic emancipation a reality. Wellington decided to sponsor the Catholic Relief Act, which passed with the votes of the Whigs in 1829. The Tory government subsequently fell as the group of Ultra Tories, who were thoroughly opposed to Catholic emancipation, voted against it at the next opportunity in $1830 .{ }^{19}$ The emancipation dealt a blow to the Tory party. ${ }^{20}$ Cannon $(1973$, p. 190$)$ even considers that "the Catholic emancipation was the battering ram that broke down the old unreformed system". Third, bad harvest and economic distress in 1829 renewed the extra-

\footnotetext{
${ }^{19}$ Two factions of the Tory party had emerged in the 1820s. The Liberal Tories favored a cautious program of administrative reform and Catholic emancipation. The Ultra Tories opposed administrative reform and were anti-Catholic. Both groups were against parliamentary reform. Wellington represented the middle ground. The Whigs had supported Catholic emancipation since 1807.

20 The Catholic Relief Act also had a side-effect in that the group of Ultra Tories at least temporarily became supporters of parliamentary reform. They argued that without sweeping reform, a new Catholic party, solidly based on the Irish constituencies, might improve its position by buying up close boroughs. The Ultra Tory Lord Blandford used this argument on 18 February 1830 when he presented a bill proposing that the rotten boroughs should be abolished and their seats transfer to the big cities and counties. The bill was defeated by 160 to 57 .
} 
parliamentary pressures for reform. For instance, the London Radical Association and the Birmingham Political Union among others were created at that time. These were to play an important role during the reform crisis in the following years.

Yet, in the first months of 1830 , it seemed unlikely that parliamentary reform would be undertaken. In February, Lord Russell's bill to give representation to Manchester, Birmingham and Leeds was defeated by 188 to 140 votes and in May, Daniel O'Connell's radical bill demanding manhood suffrage only received 13 votes in support. At the opening of the Parliament on 2 November 1830, Wellington declared that he would not bring forward reform under any circumstances, despite an unfavorable general election in July and social unrest in the Southern counties. ${ }^{21}$

\subsubsection{The reform crisis and the Great Reform Act}

The reform crisis was triggered by the fall of Wellington's government on 15 November 1830 after it had been defeated in a vote on a select committee ${ }^{22}$ that finally brought together the Ultra Tories and the Whigs in opposition to the government. This allowed Lord Grey to form the first Whig government since 1806. He immediately declared that his main objective was to introduce parliamentary reform. He carefully stressed to the committee members who were appointed to draft the bill that "the reform was to be large enough to satisfy public opinion" (Cannon, 1973, p. 204). At the same time, he also made it clear that the proposal should be based on property and existing

\footnotetext{
${ }^{21}$ The election was triggered by the death of King George IV in June 1830.

22 The select committee was to consider the Civil List, i.e., the money allocated to cover most of the expenses associated with the public duties of the King. Had Wellington's cabinet accepted the appointment of a committee on this issue, it would have been a notable surrender.
} 
franchises, thereby ruling out manhood suffrage, and that existing territorial divisions were to be maintained, thereby ruling out electoral districts of equal size.

The committee members based their deliberations on the principle that the small boroughs needed to be disenfranchised and that their seats should be given to the large cities and to the counties. ${ }^{23}$ They also favored the secret ballot, five-year Parliaments and a uniform $£ 20$ franchise for the boroughs, along with measures to cut down the cost of elections. ${ }^{24}$ However, when the proposal was presented to Lord Grey's cabinet, the secret ballot was dropped. In addition, the $£ 20$ franchise, which had been suggested to counteract the effects of the secret ballot, was reduced to $£ 10$, as many boroughs that were to keep their two seats hardly had any $£ 20$ voters. ${ }^{25}$ It was also decided that the maximum duration of a Parliament should remain at seven years while some adjustments to the redistribution of seats would be introduced.

On 1 March 1831, Lord Russell presented the first of three reform bills in the Commons. Table 3 gives an overview of the votes on the three versions of the reform bill while the Appendix outlines the content of the initial and final bills. It is clear from Table 3 that participation was very high, in particular in the first two votes where more than 90 per cent of all MPs voted. For the vote on 21 September 1831, when it had become clear that the bill would pass in the Commons, participation dropped to 73 per cent.

\footnotetext{
${ }^{23}$ The committee members used a cut-off of 2,000 inhabitants as recorded in the 1821 census to determine which boroughs should lose both seats, a cut-off of 4,000 inhabitants to determine which boroughs should lose one seat and allocated the seats to cities with more than 10,000 inhabitants. The suggested redistribution of seats to the counties was also based on population numbers (see Brock, 1973, Table 3).

${ }^{24}$ These measures concerned the registration of voters, the length of the polling (reduced to two days) and the creation of multiple polling stations.

${ }^{25}$ Even with $£ 10$ as the cut-off, some boroughs had very few voters. For example, Amersham with a population of 2612 would only have $25 £ 10$ voters.
} 
After nine days of debate, the bill passed with a single vote, 302 against 301, on 22 March 1831. It is interesting to note that the English borough MPs divided 171-200 against, but that 60 of the MPs elected in boroughs that stood to lose one of their two seats, or their two seats altogether, supported the bill. The English counties supported the bill (51 to 25), as did the MPs elected in Wales (13-10). The Scottish MPs voted against $(13-25)$ and the Irish votes in favor of reform (51-36) were pivotal. ${ }^{26}$ Table 3 clearly shows that party affiliation is a very strong predictor of the MPs' vote on the reform bill $^{27}$ : more than 96 per cent of the Whigs and all the Radicals voted in favor while more than 85 per cent of the Tories voted against. Yet, the minority of about 15 per cent "liberal" Tories who supported the bill played a key role in getting it through the Commons and more than compensated for the few dissenting Whigs who did not support the government. However, at the committee stage, Lord Grey's government was defeated on an amendment pertaining to the number of MPs to be returned in England and Wales. ${ }^{28}$ As a consequence, Lord Grey asked the King to dissolve the Parliament on 19 April 1831.

[Table 3 here]

Between October 1830 and April 1831, the British Parliament received more than 3000 petitions, mostly in favor of reform (see Cannon, 1973, p. 214). In this heated political atmosphere, the general election in 1831 was effectively a referendum on

\footnotetext{
${ }^{26}$ See Brock (1973, Table 4). Most of the Ultra Tories who had voted against Wellington's government in 1830 opposed the bill.

${ }^{27}$ The vote of each MP was obtained from the Parliamentary Debates (1830, 1831).

${ }^{28}$ Including the adjustments proposed by Grey at the opening of the committee stage, the bill implied a total loss of 31 seats across England and Wales.
} 
parliamentary reform. Many Tories were not returned and the election results gave the Whigs the majority they needed to pursue the reform.

Lord Russell introduced the second reform bill shortly after the election on 24 June 1831. Except for minor adjustments related to the boroughs that were to lose seats, it was identical to the first reform bill. At the second reading on 6 July 1831, it passed with a majority of 367 against 231 , reflecting the outcome of the 1831 general election. At the committee stage, it was, however, amended by the Tories with an important clause, suggested by the Marquis of Chandos. The Chandos clause gave the right to vote in the counties to tenants-at-will who rented property worth at least $£ 50$. It was a clear attempt to shift the balance of the bill toward the landowning aristocracy. Acknowledging that another general election would be counterproductive, Lord Grey allowed a third reading of the bill with the Chandos clause on 21 September 1831. It passed with 346 votes against 235 .

The next day, on 22 September 1831, Lord Russell presented the bill to the House of Lords. The Lords rejected the bill after five days of heated debate leading to a parliamentary deadlock. At the same time, riots broke out in many parts of the country and an alarming rise in the militancy of the political unions was observed. ${ }^{29}$

It was in this volatile political environment that Lord Russell presented the third reform bill in the House of Commons on 12 December 1831, after a period of intense lobbying of many peers and with some modifications to appease Tory critics. ${ }^{30}$ The bill

\footnotetext{
${ }^{29}$ Several people were killed in riots that took place in Bristol. In another incident, the Duke of Newcastle's castle was burnt.

${ }^{30}$ The main modifications to the bill were a remodeling of schedule B (listing the boroughs to lose one seat) where 11 boroughs were allowed to retain both seats; a redistribution of 10 extra seats to the large unrepresented towns; and a continuation of the freeman qualification in the boroughs
} 
passed the second reading with a majority of 324 against 162 on 17 December 1831 and proceeded through the committee stage without any significant amendments.

In the months leading up to the presentation of the third bill to the House of Lords, Lord Grey had suggested to King William IV that the creation of additional Whig peers might be needed to pass the reform. The King was however reluctant to commit to such a measure. The third bill was presented to the Lords on 26 March 1832. After the Bishop of London and two other leading Tory peers announced that they would support the bill, it passed the second reading in April with a narrow majority of nine votes, seven of which were proxy votes that could not be used at the committee stage. And unsurprisingly, things went wrong at the committee stage, where Duke of Wellington and Robert Peel were ready to introduce a series of significant amendments that would have changed the very nature of the reform bill. As soon as the committee stage opened on 7 May 1832, Lord Grey found himself in minority.

The next day, Lord Grey informed King William IV that he would resign failing the creation of enough Whig peers to carry the bill. Upon the King's refusal to create Whig peers, Lord Grey stepped down. The King's message to any new Tory government, however, was very clear: any government had to undertake an extensive reform measure to "secure tranquility". This put the Tories in a dilemma for which they had no solution since Robert Peel - the only Tory with any chance of commanding respect in the Commons - declined to lead a pro-reform Tory government. In the meantime, petitions kept coming in expressing significant popular support for reform while riots and talks of an armed uprising were reported throughout the country. In the end, the attempt to form a Tory government failed. Lord Grey was recalled by the King on 18 May 1832 and given 
a promise of the creation of 50 new Whig peers if need be. The third bill then passed the third reading of the Lords with a 106 to 22 majority: the Great Reform Act was a reality.

As can be seen in the Appendix, the final bill that was given royal assent on 7 June 1832 was slightly different from the first bill presented to the Commons two years earlier. It nevertheless carried out the main principles of the franchise extension and redistribution of seats. Historians have, however, argued about the significance of the bill and whether it deserves the adjective "great". Its immediate effect was to increase the number of voters from about 478,000 to about 800,000 i.e., from three to eight per cent of the total population. This basically enfranchised the middle class in the boroughs, but in most places the electorates continued to be very small. This restricted electorate, combined with the lack of a secret ballot, allowed many patrons to retain substantial influence in the elections. The redistribution of seats gave representation to the industrial centers, while the landowning aristocracy gained through an increase in the number of county seats. Contested elections became more common in the decades after the reform, up from about 30 per cent to about 60 per cent (Cannon, 1973, Appendix 3). However, the social origins and the occupations of the MPs who were returned before and immediately after the reform were very similar (Wolley, 1938).

Arguably, the Great Reform Act was mostly great because it was the first in a sequence of reforms of the British political system. It opened up the door for a reform of the municipal corporations and the poor laws in the second half of the $1830 \mathrm{~s}$, for the factory act, the repeal of the Corn Laws and the permanent introduction of the income tax in the 1840 s. It got the snowball rolling. 


\section{Hypotheses and Methodology}

In this section, we present the four hypotheses that we test and the methodology which we adopt to do so.

\subsection{Hypotheses}

The literature on franchise extension has developed several theories to explain the willingness of an elite to share its power with broader segments of the population. Our data on the votes of the MPs and on the characteristics of the constituencies where they were elected is a new and promising ground for testing these theories. We have singled out four prominent hypotheses that the data allow us to test.

Modernization theory contends that the extension of the franchise was caused by the rise of a middle class, which ultimately sought to shift the balance of power from the landowning aristocracy to the industrial and commercial interests (see Moore, 1966). Along similar lines, Congleton (2004) argues that industrialization created new economic and ideological interest groups. The rise of these groups changed the constitutional bargaining process and triggered political reforms. Both of these theories suggest that the extension of the franchise and other political reforms are driven by changes in economic and social structures and give prominence to the role of the middle class. We can summarize this as follows:

Hypothesis 1: The rise of a middle class, along with economic prosperity, generated support for the Great Reform Act.

The historical narrative stresses the role of extra-parliamentary agitation in favor of reform (Cannon, 1973, chap. 10). However, historians still debate whether the Great Reform Act was supported by large sections of the British electorate, or was a project 
entirely driven by the elite (see Evans (2000) among others). This debate motivates our second hypothesis:

\section{Hypothesis 2: The Great Reform Act had widespread electoral support.}

A prominent idea in the economics literature on franchise reform is that the elite might have extended the franchise in order to avoid a violent and costly revolution. For example, Acemoglu and Robinson $(2000,2005)$ point out that democratization can serve as a commitment device in situations in which the elite cannot promise redistribution or other public spending programs to appease the poor. ${ }^{31}$ According to this view, franchise extensions are triggered by external threats so that we may conjecture:

Hypothesis 3: The votes of the MPs were influenced by the threat of revolution.

The "Enlightenment view" argues that a significant fraction of the elite supported the extension of the franchise because their social values changed as they adopted more liberal ideas (Tilly, 2004). This line of thought suggests that the conflict within the elite about the extension of the franchise was not motivated by economic or personal interest but by ideology. ${ }^{32}$ This gives rise to the fourth hypothesis:

Hypothesis 4: The votes of the MPs were influenced by ideology rather than by economic or personal interests.

These four hypotheses all presume that voters had a minimum of independence when they elected the MPs, and that once elected, the MPs had some leeway when voting. This is unlikely to have been the case in the 56 boroughs that were

\footnotetext{
${ }^{31}$ See also Boix (2003). Justman and Gradstein (1999) envisage a more gradual process where increasing alienation of the disenfranchised leads to piecemeal suffrage reform, rather than to an abrupt extension of the franchise.

${ }^{32}$ Lizzeri and Persico (2004) also argue that the extension of the franchise was driven by a conflict of interest among the members of the elite, but they focus on conflicts along economic lines.
} 
disenfranchised by the Reform. In these constituencies, patrons tightly controlled who was elected as well as the MPs' votes. It is therefore reasonable to restrict our attention to the sample of constituencies that were not disenfranchised by the Great Reform Act. Still, as a robustness check we also ran estimations on the full sample of constituencies and on the sub-sample of disenfranchised boroughs, which we show in the Appendix. ${ }^{33}$

\subsection{Econometric design}

Figure 3 sums up our econometric approach. We estimate two equations for each of the four votes on the Reform Bills listed in Table 3. The first equation is a party affiliation equation that identifies the factors that led to the election of a Whig or of a Tory in a constituency. ${ }^{34}$ The second equation is a vote equation that explains the MP's vote in Parliament. This approach is based on the premise that the political characteristics of the constituencies, such as the voting franchise, the governance structure and the extent of aristocratic patronage, had an impact not only on the party affiliation of the elected MPs, but also on their subsequent votes on the reform bills. In contrast, we consider that the occupational structure of a constituency and its economic circumstances only affected the election of the MPs, while the MPs' occupation and personal background did not have an effect on their electoral success but had an impact on their votes.

\footnotetext{
${ }^{33}$ In the estimations over the full sample, we include a dummy variable equal to 1 for the constituencies that were disenfranchised by the Great Reform Act (the "Disenfranchised Borough" variable). It is interesting to note that many constituencies without any contested election were not disenfranchised by the Reform Act so that the "Disenfranchised Borough" and the "Uncontested Seat" variables do not overlap perfectly.

${ }^{34}$ To simplify the analysis, we assume in our estimations that Radicals and Whigs belong to the same political group (largely) in favor of reforms. In the following, we shall refer to them simply as the Whigs.
} 
[Figure 3 here]

This premise complicates the estimation of the vote and party affiliation equations, which cannot be done separately. But when estimating these two equations together, we want to avoid sample selection bias in the vote equation. Sample selection bias may arise if we do not correctly distinguish between the factors that lead to the election of a Tory or of a Whig MP on the one hand, and his support or opposition to the bill on the other hand. ${ }^{35}$ To overcome this problem, we use the two-stage estimator of Heckman (1979). In this framework, the party affiliation equation is the selection equation and the vote equation is the outcome equation. ${ }^{36}$

To explain the procedure, let us first focus on the Whigs and let the dummy variable whig take the value 1 if an elected MP from a constituency is a Whig and zero otherwise. However, it is assumed that we only observe a vote in favor of the reform bill if an unobserved latent variable, whig*, exceeds a threshold. That is

$$
\text { whig }^{*}=\gamma_{0}+X_{1}{ }^{\prime} \gamma_{1}+X_{2}{ }^{\prime} \gamma_{2}+\eta
$$

and

$$
\text { whig }=\left\{\begin{array}{c}
1 \text { if } \text { whig }^{*} \geq 0 \\
0 \text { otherwise }
\end{array}\right.
$$

\footnotetext{
${ }^{35}$ It may even be hypothesized that some factors explain why a MP voted in favor of the reform in one of the earlier (respectively, later) votes but not in the subsequent (preceding) votes. This explains why we report four first-stage estimations, one for each of the four votes, even though our sample only covers two general elections.

${ }^{36}$ The analogy between this study and Heckman (1979)'s study on the determinants of female wages is as follows. To understand the determinants of female wages, one cannot only examine the individual characteristics of women who work. In addition, one cannot assume that the decision to work and the determinants of wages are identical. Therefore, in a first step, one should explain why some women work while others choose not to. In a second step, the determinants of female wages can be analyzed on a sample that is restricted to working women.
} 
where $X_{1}$ and $X_{2}$ are two matrices of explanatory variables and $\eta$ is an error term that follows a standard normal distribution. The matrix $X_{1}$ includes the variables related to the political and institutional characteristics of each constituency while the matrix $X_{2}$ includes the variables related to the occupational and economic structure of the constituency. The selection equation in the first stage of Heckman's two-stage procedure is estimated as a probit model and identifies the characteristics of the constituencies that returned Whig MPs

$$
\operatorname{Pr}(\text { whig }=1)=F\left(\gamma_{0}+X_{1}^{\prime} \gamma_{1}+X_{2}^{\prime} \gamma_{2}\right)
$$

where F represents the standard normal cumulative distribution function.

From the estimated parameters of the probit model in equation (3), we compute the estimated hazard rate $\hat{\lambda}$. It is equal to

$$
\hat{\lambda}=\frac{f\left(X_{1} \cdot \hat{\gamma}_{1}+X_{2} \cdot \hat{\gamma}_{2}\right)}{F\left(X_{1} \cdot \hat{\gamma}_{1}+X_{2} \cdot \hat{\gamma}_{2}\right)}
$$

where $\left(\hat{\gamma}_{1}, \hat{\gamma}_{2}\right)$ is the vector of estimated parameters from equation (3) and $f($.$) is the$ probability density function of a standard normal distribution. We can then use $\hat{\lambda}$ to normalize the mean of the true error term of the vote equation to zero. This generates consistent estimators for the second step of the two-stage procedure. The outcome equation, i.e., the vote equation, can then be estimated by the following probit model

$$
\operatorname{Pr}(\text { for }=1)=F\left(\phi_{0}+X_{1}^{\prime} \phi_{1}+X_{3}^{\prime} \phi_{2}+\sigma \cdot \hat{\lambda}\right)
$$

where the dummy variable for equals the value 1 if the Whig MP voted in favor of the reform and 0 otherwise, $\sigma$ is the standard deviation of the true error term of the vote 
equation, and $X_{3}$ is a matrix of variables related to the MPs' occupations and background.

If the coefficient that is associated with the hazard rate is insignificant at the 5 per cent level, the estimation of the vote equation in the second stage is not affected by a sample selection bias. In other words, the estimation of the two equations correctly distinguishes between, on the one hand, the factors that led to the elections of Whig MPs, and, on the other hand, the factors that explain the votes of the elected MPs.

We repeat this estimation procedure to explain the votes of the Tory MPs who opposed the reform. We use in equation (3) the variable tory instead of whig, where tory equals 1 if a Tory MP was elected and 0 otherwise. In equation (5), we use the variable against instead of for, where against equals 1 if the Tory MP opposed the reform and 0 otherwise.

\section{Results}

The main results are presented in Tables 4 and 5. As noted above, the underlying estimations are based on the sub-sample of constituencies that were not disenfranchised. ${ }^{37}$ More specifically, Table 4 shows the estimated vote and party affiliation equations for the Whig MPs while Table 5 presents the equivalent estimations for the Tory MPs. Each Table has two panels. In the top panel, we report the estimations of the vote equation and in the lower panel, we display the estimates of the party affiliation equation. Accordingly,

\footnotetext{
37 The corresponding estimations for the whole sample and for the sub-sample of disenfranchised constituencies are reported in the Appendix. The results of these additional estimations are consistent with the conclusions we draw below.
} 
each Table contains four estimations, one for each of the four votes that took place on 22 March 1831, 6 July 1831, 20 September 1831 and 17 December $1831 .^{38}$

[Table 4 here] [Table 5 here]

\subsection{The middle class, economic prosperity and the Great Reform Act}

To test Hypothesis 1, which contends that economic prosperity and the rise of the middle class were the causes of reform, we examine the impact of the economic circumstances and the occupational structure of the constituencies on the election of MPs. In particular, Hypothesis 1 implies that the constituencies that were thriving at the time of the reform would return pro-reform Whigs, while the constituencies that were undergoing an economic decline would return anti-reform Tories. The two variables - Thriving Economy and Declining Economy - which pertain to the economic circumstances in the constituencies allow us to perform this test directly.

The lower panel of Table 5 shows that constituencies with a thriving economy were more likely to return Tories, while the evidence in Table 4, if anything, suggests that Whigs were unlikely to be returned in constituencies with a declining economy. It would thus appear, contrary to Hypothesis 1, that constituencies with prosperous economic circumstances supported politicians who were, in general, opposed to the Great Reform Act.

In addition, Hypothesis 1 implies that constituencies which were mainly populated by groups associated with a burgeoning middle-class, such as traders, artisans or

\footnotetext{
${ }^{38}$ We selected the shown specifications where the hazard rate $\lambda$ is insignificant, indicating that the vote equation is not affected by a selection bias. As a result, the reported estimations do not necessarily contain the same set of variables.
} 
professionals, would return pro-reform Whigs. ${ }^{39}$ We test this conjecture by examining the impact of the variables capturing the occupational structure of the constituencies on the elections of the MPs in the first step of the Heckman model.

The results in lower panel of Table 4 suggest that Whigs were more likely to be returned in constituencies with a high share of agricultural workers, industry workers and artisans in the 1831 election. Table 5 is consistent with this, as it shows that Tories were less likely to be returned in constituencies dominated by these occupational groups. Taken together, these observations suggest that the economic changes that were producing more cohesive working and middle classes might have been an engine for reform. This lends some support to Hypothesis 1.

All in all, it is possible to reconcile our conflicting results by distinguishing between the long-term and the short-term. In the long-term, economic growth created groups of affluent individuals, distinct from the landowning aristocracy, who wanted to have a say in political affairs. In the short-term, the downturn in economic activity made these individuals bolder in their demands. But they met popular opposition originating from the constituencies that withstood recession and economic hardship. This interpretation would reconcile the emerging middle classes' support for reform with the historical narrative alluded to above which suggests that the reform movement was given a new impetus by the recession that started in 1829 .

\subsection{Elitist and popular support for the Great Reform Act}

Hypothesis 2 suggests that the Great Reform Act enjoyed popular support among the electorate of the Unreformed Parliament. To test this, we investigate whether the

\footnotetext{
39 Even though middle-class voters could not always vote, it may be conjectured that the MPs were receptive to the demands of middle-class residents living in their constituencies.
} 
differences in the electoral success of the pro-reform Whigs and anti-reform Tories can be explained by the franchise type and the degree of patronage in the constituencies where they were elected. If the reform had popular support, then the Whigs would mostly have been returned in large and open constituencies. Conversely, if the bulk of the electorate opposed the reform which was merely a project driven by the elite, then the Whigs would have been elected in close boroughs where the influence of patrons was high and the electorate small.

The lower panels of Tables 4 and 5 show that Whigs (respectively, Tories) were more (less) likely to be returned in boroughs with a scot and lot franchise, which often allowed for a large electorate. In addition, the Whigs (Tories) were likely to lose (win) in boroughs with a corporation franchise and in burgage boroughs, where the electorate was often very restricted. Furthermore, the lower panels of Tables 4 and 5 indicate that constituencies with a municipal corporation, which could be relatively free from aristocratic influence, were more likely to return Whig MPs and less likely to return Tory MPs. We can also note that Tories were elected in constituencies with a substantial degree of aristocratic influence, while Whigs were not, at least in the 1831 election.

Overall, these observations suggest that pro-reform Whigs were returned in constituencies with open elections while Tories were typically not. In addition, Tory candidates were usually successful in boroughs where aristocratic influence was high. This is consistent with Hypothesis 2. As a matter of fact, the Tories virtually lost all popular support in the 1831 general election. Of the 187 Tory candidates returned by the English boroughs, 165 represented boroughs that were to lose their seats or with less than 400 voters, and only six of the MPs returned in the counties were Tories (Cannon, 1973, 
p. 221). Still, the Great Reform Act could clearly not have been adopted without the support from a substantial part of the Whig elite. Indeed, many Whig MPs were returned in counties and in boroughs where patrons had at least some control over the electorate.

\subsection{The threat of revolution and the Great Reform Act}

In the absence of a direct constituency-specific measure of the threat of revolution, our test of Hypothesis 3 is indirect: it is based on the fact that the perceived or real threat of political violence substantially increased during the late autumn of 1831 . This is clearly demonstrated by Tilly (1995)'s work on contentious gatherings in Great Britain. He reports that there were less than 50 such gatherings in June, July and August 1831, but more than 300 in October 1831. If the threat of revolution exercised an influence on the attitude of the MPs towards reform, Hypothesis 3 suggests that there would be systematic differences between the votes held in July 1831 and in December 1831. In particular, we should observe a dramatic change in the influence of patrons on the votes of the MPs. In the low-tension environment of July 1831, they should have been hostile to reform and instructed the MPs under their influence to oppose the reform. But in the last months of 1831 , which were characterized by high political tensions, they should have abandoned their stance against the extension of the franchise and encouraged the MPs under their influence to support the reform bill.

An important piece of evidence in support of Hypothesis 3 comes from Table 4. From the top panel, we note a shift in the vote of Whig MPs who were returned in the constituencies where patrons partially controlled the electorate: these MPs did not support parliamentary reform until the vote held on 17 December 1831 . This result can be 
interpreted as evidence that the increase in the threat of revolution in the autumn of 1831 caused some Whig patrons to change their mind and support reform.

In addition, the threat of revolution seemed to have had an impact on the vote patterns of one particular group of Whig MPs: those with an army career. While these MPs were likely to vote against the reform bill in the first critical vote held on 22 March 1831, they did not demonstrate any opposition in the subsequent votes. It may be hypothesized that Whig officers did not want to take part in suppressing the revolt that might have been triggered if the Parliament failed to extend the franchise.

However, the threat of revolution did not soften the stance of Tory MPs against the reform, as can be seen in the top panel of Table 5. Their anti-reform stance was supported by their patrons, whose influence is more significant in the final than in the first votes. This observation suggests that the mobilization of the Tory aristocrats against the reform bill in the 1831 election, which was almost exclusively fought on the reform question, prevented a landslide victory for the Whigs.

Overall, our results suggest that the threat of revolution did influence some Whig patrons and MPs who initially opposed the reform and made them change their mind. However, they also indicate that social unrest hardened the anti-reform stance of the Tory MPs and of their patrons. The evidence in favor of Hypothesis 3 is, therefore, mixed. It points to an interesting asymmetry in the effects of external threats in the voting behavior of reluctant reformers and anti-reform hardliners.

\subsection{Ideology, self-interest and the Great Reform Act}

Insofar as opposite ideologies can be captured by party affiliations, Hypothesis 4 can be tested by investigating whether the voting patterns of Whig and Tory MPs were 
dissimilar. These differences should be most pronounced in the constituencies that were either fully or partially controlled by patrons. This is because Whig (respectively, Tory) patrons would have instructed the MPs whose vote they controlled to support (oppose) the reform bills. However, if Hypothesis 4 is false so that economic and social interests, rather than ideology, drove the vote, then both Whig and Tory patrons should have opposed the extension of the franchise. Moreover, we would have to reject Hypothesis 4 if Tory and Whig MPs with the same occupations voted in the same manner and not according to their party affiliation as this would indicate that personal interests were more important than ideology in shaping their votes.

The upper panels of both Tables 4 and 5 suggest that the votes of Whig and Tory MPs were very different and, as such, mirrored the opposite stance of their patrons. Indeed, a substantial number of Whig patrons allowed, and maybe even instructed, their MPs to support the Reform Act, even tough it would undermine their political influence. It would therefore seem that ideology played a significant part in the success of the reform bill.

Ideology is also a convincing explanation for the support that Tory financiers gave to the reform bill (see the upper panel of Table 5). They were the sole group of Tory MPs to consistently support the extension of the franchise. It may be that, because of their profession, they were more in touch with the aspirations of the emerging middle-class than Tory landowners and therefore felt less threatened by the prospect of reform.

However, some of our results suggest that many MPs were motivated by their selfinterest, and not by principles, when they voted. Not surprisingly, both the Whigs and the Tories who were returned in boroughs that were to be disenfranchised tended to oppose 
the reform (See Tables A3 and A5 in Appendix). More interestingly, we find that Whig industry owners were likely to oppose the reform during the third reading of the second reform bill on 17 December 1831 . It is possible that Whig industry owners worried that a reform would give industry workers the power to demand new economic rights. They were joined in their opposition to the bill by Tory MPs who had a relative in Parliament. These MPs were undoubtedly heirs to political dynasties and they were mainly interested in preserving the old political order.

All in all, our results clearly suggest that ideology was an important engine of parliamentary reform. At the same time, the evidence also implies that the opposition to the reform was, at least partly, driven by economic and social interests, i.e., by patronage and by the MPs' personal interests.

\section{Conclusion}

In this study, we offer a new approach to the study of political reform and democratization. We provide an econometric analysis of the factors that led to the adoption of the Great Reform Act in Great Britain in 1832. We assess the relative importance of factors such as economic growth, ideology or the threat of revolution in explaining the willingness of an elite to extend the franchise. For this purpose, we collected an extensive dataset from primary and secondary sources on the British economy and polity under the Unreformed Parliament.

The study yields four main results. First, modernization theory only receives mixed support. While the economic changes that created more cohesive working and middle classes spurred the reform process, prosperous constituencies in the 1830 s were likely to return anti-reform MPs to Parliament. Second, the reform enjoyed some measure of 
popular support. In particular, we find that pro-reform MPs were more likely to be elected in constituencies with relatively large electorates and contested elections. Third, the threat of revolution had an asymmetric impact on the voting behavior of the proreform Whigs and of the anti-reform Tories. It convinced reluctant reformers among the Whig MPs and their patrons - to support the bill, but strengthened the anti-reform stance of the Tories. Fourth, ideology played a critical role in the adoption of the Great Reform Act. Nonetheless, self-interest and political expedience also explained the votes of many MPs.

Our findings have interesting implications for the broader literature on franchise reform. First, the theoretical model of franchise reform developed by Acemoglu and Robinson $(2000,2006)$ assumed that all the members of the elite perceive the threat of revolution similarly and agree on how to avoid violent political change. However, our results suggest that the members of the elite were divided on the appropriate answer to the threat of revolution. Therefore, an alternative modeling strategy would take into account that some members of the elite may prefer concessions, i.e., an extension of the franchise, while others prefer repression. This would add an additional dimension of conflict to the model which may generate richer and more realistic regime dynamics. Second, Acemoglu et al. (2008) recently challenged modernization theory and showed that the existence of a causal link between economic development and democratization is doubtful. Our results cast further doubt on the relevance of this theory. Third, O'Gorman (1989) challenged the view that the Unreformed Parliament was entirely corrupt and controlled by patrons. Instead, he painted a picture of "vitality" and suggested that the old system was fairly representative and open to competition. Our results clearly show that 
patrons played an important role in the Unreformed Parliament and that they controlled many MPs. Nevertheless, we do find some evidence of "vitality". In particular, the votes of many MPs reflected their personal interests rather than that of their patrons or party.

Our approach to the study of democratization may be used to analyze other reforms beside the Great Reform Act. It only requires that the politicians who were elected under pre-reform rules voted on the extension of franchise. The subsequent reforms of the British Parliament in 1867, 1884, and 1918 are, therefore, promising cases for further study. Another promising avenue of future research pertains to the study of the many failed reform attempts that took place in the 50 years prior to the Great Reform Act. 


\section{References}

Acemoglu, D., Robinson J.A., 2000. Why did the West extend the franchise? Democracy, inequality, and growth in historical perspective. Quarterly Journal of Economics 115(4), 1167-1199.

Acemoglu, D. and Robinson, J.A., 2005. Economic origins of dictatorship and democracy. Cambridge, UK: Cambridge University Press.

Acemoglu, D., Johnson, S. and Robinson, J.A., 2001. The colonial origins of comparative development: an empirical investigation. American Economic Review 91, 13691401.

Acemoglu, D., Johnson, S., Robinson, J.A. and Yared, P., 2008. Income and democracy, American Economic Review 98, 808-842.

Aidt, T.S., Dutta, J., Loukoianova, E., 2006. Democracy comes to Europe: Franchise extension and fiscal outcomes 1830-1938. European Economic Review 50, 249283.

Aidt, T.S., Jensen, P., 2008a. Tax structure, size of government and the extension of the voting franchise in Western Europe, 1860-1938. International Tax and Public Finance, in press.

Aidt, T.S., Jensen, P., 2008b. The taxman tools up: An event history study of the introduction of the personal income tax, 1815-1941. Journal of Public Economics, in press.

Boix, C., 2003. Democracy and redistribution. Cambridge University Press, Cambridge, UK. 
Bourguignon, F., and T. Verdier, 2000. Oligarchy, democracy, inequality and growth, Journal of Development Economics, 62(2), 285-313.

Brock, M., 1973. The Great Reform Act. London: Hutchinson University Library.

Cannon, John Ashton, 1973. Parliamentary reform, 1640-1832, Cambridge University Press, Cambridge, UK.

Census of England and Wales, 1831, House of Commons, U.K.

Congleton, R.D. 2004. Economic development and democracy: does industrialization lead to universal suffrage? Homo Economicus 21, 283-311.

Congleton, R., 2007. From royal to parliamentary rule without revolution: the economics of constitutional exchange within divided governments, European Journal of Political Economy 23, 261-284.

Croker, J.W., 1884. The correspondence and diaries of the Late Right Honourable John Wilson Croker, edited by Louis J. Jennings, Charles Schribner's sons, New York, NY.

Dod's Parliamentary Companion, various years, Dod, London, U.K.

Evans, E.J. 2000. Parliamentary reform, 1770-1918, Pearson Education, Seminar Studies in History.

Gradstein, M., 2007. Inequality, democracy and the protection of property rights, Economic Journal, 117, 252-269.

Heckman, J.J., 1979. Sample selection bias as a specification error, Econometrica 47, $153-161$.

Hettich, W., Winer, S., 1988. Economic and political foundations of tax structure. American Economic Review 78, 701-12. 
Husted, T.A., Kenny, L.W., 1997. The effect of the expansion of the voting franchise on the size and scope of government. Journal of Political Economy 105, 54-82.

Janowitz, M. 1976. Military institutions and citizenship in Western societies. Armed Forces and Society (2), 185-203.

Judd, Gerrit Parmele, 1955. Members of Parliament, 1734-1832, Yale University Press, New Haven Connecticut.

King, Gary, 1997. A solution to the ecological inference problem, Princeton University Press, Princeton, NJ.

Justman, M., Gradstein, M., 1999. The industrial revolution, political transition, and the subsequent decline in inequality in 19th-century Britain. Explorations in Economic History 36, 109-127.

Lindert, P.H., 1994. The rise in social spending 1880-1930. Explorations in Economic History $31,1-37$

Lott, J. R., Kenny, L.W., 1999. Did women's suffrage change the size and scope of government? Journal of Political Economy, 107, 1163-1198.

Lizzeri, A., Persico, N., 2004. Why did the elites extend the suffrage? Democracy and the scope of government, with an application to Britain's "Age of Reform". Quarterly Journal of Economics 119 (2), 707-765.

Machin, Ian, 2001. The rise of democracy in Britain, 1830-1918, Macmillan Press, London, UK.

Meltzer, A.H., Richard S.F, 1983. Tests of a rational theory of the size of government, Public Choice 41, 403-418. 
Moore, Barrington, 1966. The social origins of dictatorship and democracy, Boston, MA: Beacon Press.

Namier, Lewis Bernstein, Brooke John, 1964. The House of Commons, 1754-1790, Oxford University Press, Oxford, UK.

O'Gorman, F. 1989. Voters, Patrons and Parties: The Unreformed Electoral System in. Hanoverian England 1734-1832. Oxford University Press, Clarendon Press, Oxford, U.K.

Parliamentary Debates, various years, Hansard, London.

Pearce, R. and Stearn, R., 1994. Government and Reform: Britain 1815-1918. Hodder Murray.

Persson, T., Tabellini, G., 2003. The economic effects of constitutions. Cambridge, Mass., The MIT Press.

Philbin, J. Holladay, 1965. Parliamentary representation, 1832, England and Wales, Yale University Press, New Haven, Connecticut.

Porrit, Edward, Porritt Annie G., 1903. The unreformed House of Commons, Vol. 1: England and Wales, Cambridge University Press, Cambridge, UK.

Schonhardt-Bailey, C., 1998. Parties and interests in the "marriage of iron and rye", British Journal of Political Science 28(2), 291-332.

Schonhardt-Bailey, Cheryl. 2006. From the Corn Laws to free trade: interests, ideas and institutions in historical perspective. MIT Press, Cambridge, MA.

Stookes Smith, Henry, 1973. The Parliaments of England, Political Reference Publications, Chichester, UK. 
Thorne, R.G., 1986. The House of Commons, 1790-1820, Oxford University Press, Oxford, UK.

Tilly, C., 1995. Popular contention in Great Britain, 1758-1834, Harvard University Press, Cambridge MA.

Tilly, C., 2004. Contention and Democracy in Europe, 1650-2000. Cambridge University Press, Cambridge, UK.

Whitfield, B., 2001. The Extension of the Franchise, 1832-1931, Heinemann, Heinemann Advanced History Series.

Wolley, C.F., 1938. The Personnel of the Parliament of 1833. The English Historical Review 53 (210), 240-262. 


\section{Appendices.}

A1. Appendix A: The franchise bills.

On 1 March 1831, Lord Russell presented the first of three reform bills in the Commons. The main features of this first reform bill were (Brock, 1973, Table 3):

1) 60 boroughs (listed in schedule A) were to be disenfranchised entirely, a further 47 boroughs (listed in schedule B) were to lose one seat, and Weymouth was to lose two seats out of four.

2) 11 new two-seat and 21 one-seat borough constituencies were to be created (in the previously un-represented towns with over 10,000 inhabitants listed in schedule C) and 6 new seats should be created in the un-represented parts of London (schedule D).

3) Each of the three Ridings of Yorkshire were to have two seats; 26 of the other English counties were to gain two additional seats, up from two to four (schedule E); the Isle of Wight was to be given one seat.

4) The county franchise was to be given to all 40 -shilling freeholders, to $£ 10$ per year copyholders and to $£ 50$ per year leaseholders (with a lease of 21 years at least).

5) The borough franchise was to be given to adult male occupiers of houses worth at least $£ 10$ per year who had owned the property for at least one year, had paid all the relevant taxes on it and had not received poor relief in the previous year. All existing electors were to retain their right to vote for life if resident.

6) Open voting was to remain.

7) The maximum length of a Parliament was set at seven years.

8) A register of voters was to be established in both boroughs and counties.

The final bill that was given Royal assent on 7 June 1832 was different from that first presented to the Commons two years earlier, but carried over the main principles (Brock, 1973, Table 3):

1) 56 boroughs (listed in schedule A) were disenfranchised entirely, a further 30 boroughs (listed in schedule B) lost one seat, and Weymouth lost two members out of four. 
2) 22 new two-seat and 21 one-seat borough constituencies were created in the previously un-represented towns with over 10,000 inhabitants and in London.

3) Each of the three ridings of Yorkshire was given two seats; 26 of the other English counties gained two extra seats, up from two to four; the Isle of Wight was given one seat.

4) The county franchise was to be given to all 40-shilling freeholders; to $£ 10$ per year copyholders; to $£ 50$ per year leaseholders (with a lease of 20 years at least); to $£ 10$ per year leaseholders (with a lease of 60 years at least); to $£ 50$ tenant-at-will, if occupiers.

5) The borough franchise was given to adult male occupiers of houses worth at least $£ 10$ per year who owned the property for at least one year, had paid all the relevant taxes on it and had not received poor relief in the previous year. The rights of the current freemen were extended to the future freemen, provided these rights a) were acquired through birth or apprenticeship and b) if acquired through birth, these rights must have been derived from qualification existing before March 1831. All other existing electors were to retain their right to vote for life if resident.

6) Open voting was to remain.

7) The maximum length of a Parliament was set at seven years.

8) A register of voters was to be established in both boroughs and counties.

\section{A.2. Appendix B: Descriptive statistics.}

Table A1 presents some descriptive statistics for the variables we use in this study.

[Table A1 here]

\section{A.3. Appendix C: Supplementary estimations.}

The Tables we present below display estimation results on the whole sample and on the sub-sample of disenfranchised boroughs, for the Whigs and the Tories. They are organized like Tables 4 and 5.

[Table A2 here][Table A3 here] [Table A4 here] [Table A5 here] 
Table 1. The Size and Type of the Borough Constituencies in England and Wales in 1830.

\begin{tabular}{|l|c|c|c|c|c|c|c|}
\hline & \multicolumn{6}{|c|}{ Franchise type } \\
\hline Size of the electorate & $\begin{array}{c}\text { A } \\
\text { Scot and Lot }\end{array}$ & $\begin{array}{c}\text { B } \\
\text { Potwalloper }\end{array}$ & $\begin{array}{c}\text { C } \\
\text { Freeman }\end{array}$ & $\begin{array}{c}\text { D } \\
\text { Freeholder }\end{array}$ & $\begin{array}{c}\text { E } \\
\text { Corporation }\end{array}$ & $\begin{array}{c}\text { F } \\
\text { Burgage }\end{array}$ & Total \\
\hline 1. Over 5000 & 1 & 1 & 5 & & & & 7 \\
\hline $2.1001-5000$ & 6 & 2 & 25 & 4 & & & 37 \\
\hline $3.601-1000$ & 8 & 5 & 11 & 1 & & 25 \\
\hline $4.301-600$ & 11 & 1 & 16 & & & & 28 \\
\hline $5.101-300$ & 8 & 5 & 12 & 1 & 1 & 10 & 37 \\
\hline $6.51-100$ & 4 & & 5 & & 2 & 10 & 21 \\
\hline 7.50 or less & 2 & & 14 & & 27 & 15 & 58 \\
\hline Total & 40 & 14 & 88 & 6 & 30 & 35 & 213 \\
\hline
\end{tabular}

Notes:

- The coding of the English boroughs is given in the notes to Table 2 in Brock (1973). For the Welsh boroughs the coding is as follows. A3. Flint. A4. Haverfordwest. E7. Beaumaris. C2. Pembroke. C3. Cardiff, Carmartheren. C4. Cardigan, Carnarvon, Denbigh. C5. Radnor. C7. Brecon. Information on the number of voters in Montgomery, which was a freeman borough, is not available.

- In the freemen boroughs, all individuals with the freeman status were allowed to vote, whether or not they resided in the boroughs. The freeman status could be inherited, acquired by serving an apprenticeship in the borough, or received as an honor from the borough's corporation.

- In the scot and lot boroughs, inhabitants who paid the poor rates could vote.

- In the potwalloper boroughs, all the resident householders who "had a family and boiled a pot" could vote.

- In the freeholder boroughs, the franchise requirement was the same as in the English counties, i.e., a 40shilling qualification.

- In the burgage boroughs, the owners of a property with an old form of tenure, called the burgage, could vote. These were often limited to plots of land that had formed the borough when it was first laid out and could be owned by a single person.

- In the corporation boroughs, only members of the local town council, called the corporation, could vote. The franchise was therefore restricted to the mayor and members of the town corporation who were coopted by a small group of burgesses rather than elected. This often resulted in very narrow electorates.

- Sources: Brock (1973, Table 2) for the 202 English boroughs, Philbin (1965), and the authors' own coding for the Welsh boroughs. 
Table 2. Aristocratic influence and patronage in England and Wales under the Unreformed Parliament.

\begin{tabular}{|c|c|c|c|c|c|c|}
\hline Patronage & $\begin{array}{c}\text { English } \\
\text { Boroughs }\end{array}$ & $\begin{array}{c}\text { Welsh } \\
\text { Boroughs }\end{array}$ & $\begin{array}{c}\text { English } \\
\text { Counties }\end{array}$ & $\begin{array}{c}\text { Welsh } \\
\text { Counties }\end{array}$ & $\begin{array}{c}\text { English } \\
\text { Universities }\end{array}$ & \begin{tabular}{c} 
Total \\
\hline High influence
\end{tabular} \\
73 & 2 & 8 & 4 & 0 & 87 \\
\hline Some influence & 70 & 8 & 16 & 7 & 0 & 101 \\
\hline Low influence & 25 & 1 & 10 & 0 & 2 & 38 \\
\hline No influence & 20 & 1 & 5 & 1 & 0 & 27 \\
\hline Treasury borough & 13 & 0 & $1^{\mathrm{b}}$ & 0 & 0 & 14 \\
\hline Total & $201^{\mathrm{a}}$ & 12 & 40 & 12 & 2 & 267 \\
\hline
\end{tabular}

Notes:

- a. We do not have information for New Sarum (also known as Salisbury).

•b. Hampshire would always return "court nominees".

- Source: Own coding based on Philbin (1965). 
Table 3. Overview of the four votes on the Reform Bills examined in the study.

\begin{tabular}{|c|c|c|c|c|}
\hline Data of vote & Bill & Parliament & Votes for & Votes against \\
\hline 22 March 1930 & Second reading of the first Reform Bill. & 1830 Parliament & $\begin{array}{c}\text { Whig: } 248 \\
\text { Radical: } 6 \\
\text { Tory: } 48 \\
\text { Total: } 302(238)\end{array}$ & $\begin{array}{c}\text { Whig: } 8 \\
\text { Radical: } 0 \\
\text { Tory: } 293 \\
\text { Total: } 301(240)\end{array}$ \\
\hline 6 July 1831 & Second reading of the second Reform Bill. & 1831 Parliament & $\begin{array}{c}\text { Whig: } 316 \\
\text { Radical: } 10 \\
\text { Tory: } 41 \\
\text { Total: } 367(285) \\
\end{array}$ & $\begin{array}{c}\text { Whig: } 5 \\
\text { Radical: } 0 \\
\text { Tory: } 227 \\
\text { Total: } 232(192) \\
\end{array}$ \\
\hline 21 September 1831 & Third reading of the second Reform Bill. & 1831 Parliament & $\begin{array}{c}\text { Whig: } 302 \\
\text { Radical: } 10 \\
\text { Tory: } 34 \\
\text { Total: } 346(274)\end{array}$ & $\begin{array}{c}\text { Whig: } 5 \\
\text { Radical: } 0 \\
\text { Tory: } 232 \\
\text { Total: } 235(179)\end{array}$ \\
\hline 17 December 1831 & Second reading of the third Reform Bill. & 1831 Parliament & $\begin{array}{c}\text { Whig: } 285 \\
\text { Radical: } 4 \\
\text { Tory: } 35 \\
\text { Total: } 324(266)\end{array}$ & $\begin{array}{c}\text { Whig: } 4 \\
\text { Radical: } 0 \\
\text { Tory: } 158 \\
\text { Total: } 162(131)\end{array}$ \\
\hline
\end{tabular}

Notes:

- The votes for and against on the Reform Bills refer to all MPs, including those representing Scotland and

Ireland. The votes in the bracket refer to the MPs from England and Wales.

- Source: Parliamentary Debates, various years. 
Table 4. Determinants of the Whigs' election and support for reform: all the constituencies excluding the disenfranchised boroughs

Vote equation of the Whig support for Reform

22 March $1831 \quad 6$ July $1831 \quad 20$ September $1831 \quad 17$ December 1831

\begin{tabular}{|c|c|c|c|c|c|}
\hline \multirow[t]{8}{*}{ Patronage } & High influence & 0.01 & 0.003 & 0.00 & 0.037 \\
\hline & & {$[0.106]$} & {$[0.060]$} & {$[0.034]$} & {$[0.024]$} \\
\hline & Some influence & -0.054 & 0.016 & 0.006 & 0.044 \\
\hline & & {$[0.085]$} & {$[0.060]$} & {$[0.033]$} & {$[0.023]^{*}$} \\
\hline & No influence & 0.212 & 0.02 & 0.038 & 0.042 \\
\hline & & {$[0.106]^{* *}$} & {$[0.054]$} & {$[0.030]$} & {$[0.021]^{*}$} \\
\hline & Treasury borough & -0.111 & 0.072 & 0.034 & 0.026 \\
\hline & & {$[0.127]$} & {$[0.070]$} & {$[0.039]$} & {$[0.027]$} \\
\hline \multirow{6}{*}{$\begin{array}{c}\text { Governance } \\
\text { structure }\end{array}$} & Municipal corporation & 0.044 & -0.027 & 0.076 & 0.003 \\
\hline & & {$[0.111]$} & {$[0.051]$} & {$[0.033]^{* *}$} & {$[0.021]$} \\
\hline & Representative borough & & -0.186 & & -0.094 \\
\hline & & & {$[0.057]^{* * *}$} & & {$[0.022]^{* * *}$} \\
\hline & County & 0.139 & & 0.1 & \\
\hline & & {$[0.122]$} & & {$[0.033]^{* * *}$} & \\
\hline \multirow{12}{*}{$\begin{array}{c}\text { Franchise } \\
\text { type }\end{array}$} & Burgage franchise & 0.004 & -0.076 & -0.043 & 0.007 \\
\hline & & {$[0.115]$} & {$[0.059]$} & {$[0.033]$} & {$[0.024]$} \\
\hline & Corporation franchise & 0.235 & 0.115 & 0.033 & 0.047 \\
\hline & & {$[0.141]^{*}$} & {$[0.086]$} & {$[0.048]$} & {$[0.033]$} \\
\hline & Freeman franchise & 0.131 & -0.004 & -0.025 & -0.016 \\
\hline & & [0.083] & {$[0.040]$} & {$[0.022]$} & {$[0.016]$} \\
\hline & Scot and lot franchise. & -0.027 & 0.041 & 0.025 & 0.012 \\
\hline & & [0.099] & {$[0.052]$} & {$[0.029]$} & {$[0.021]$} \\
\hline & Freehold franchise. & 0.195 & 0.051 & -0.013 & -0.009 \\
\hline & & {$[0.229]$} & {$[0.083]$} & {$[0.051]$} & {$[0.032]$} \\
\hline & Household franchise & 0.196 & 0.042 & 0.025 & -0.013 \\
\hline & & {$[0.354]$} & {$[0.171]$} & {$[0.095]$} & {$[0.065]$} \\
\hline \multirow{15}{*}{$\begin{array}{c}\text { MPs' } \\
\text { occupations \& } \\
\text { characteristics }\end{array}$} & & & & & \\
\hline & Army career & -0.294 & 0.069 & 0.015 & 0.02 \\
\hline & & {$[0.097]^{* * *}$} & {$[0.052]$} & {$[0.029]$} & {$[0.021]$} \\
\hline & Financiers & -0.079 & 0.065 & 0.042 & 0.02 \\
\hline & & {$[0.110]$} & {$[0.054]$} & {$[0.029]$} & {$[0.023]$} \\
\hline & Dynasty heir & -0.098 & 0.05 & 0.025 & 0.008 \\
\hline & & {$[0.075]$} & {$[0.039]$} & {$[0.022]$} & {$[0.016]$} \\
\hline & Industrialist & -0.114 & -0.087 & -0.065 & -0.089 \\
\hline & & {$[0.103]$} & {$[0.068]$} & {$[0.039]^{*}$} & {$[0.028]^{* * *}$} \\
\hline & Jurist & -0.139 & 0.051 & 0.027 & 0.011 \\
\hline & & {$[0.135]$} & {$[0.052]$} & {$[0.028]$} & {$[0.020]$} \\
\hline & Merchant & 0.00 & -0.012 & 0.021 & 0.013 \\
\hline & & {$[0.106]$} & {$[0.059]$} & {$[0.034]$} & {$[0.024]$} \\
\hline & Relatives in Parliament & -0.016 & -0.018 & -0.029 & -0.019 \\
\hline & & {$[0.066]$} & {$[0.034]$} & {$[0.018]$} & {$[0.014]$} \\
\hline \multirow{6}{*}{$\begin{array}{c}\text { Political } \\
\text { circumstances }\end{array}$} & Uncontested seat & & & & \\
\hline & $(1800-1831)$ & $\begin{array}{c}0.055 \\
{[0.097]}\end{array}$ & $\begin{array}{c}0.007 \\
{[0.047]}\end{array}$ & $\begin{array}{c}0.044 \\
{[0.027]}\end{array}$ & {$[0.019]$} \\
\hline & Seats after Reform & & 0.037 & 0.042 & 0.012 \\
\hline & & & {$[0.037]$} & {$[0.022]^{*}$} & {$[0.015]$} \\
\hline & Constant & 0.838 & 0.853 & 0.788 & 0.95 \\
\hline & & {$[0.160]^{* * *}$} & {$[0.101]^{* * *}$} & {$[0.068]^{* * *}$} & {$[0.041]^{* * *}$} \\
\hline
\end{tabular}

Continuing next page 
Party affiliation equation of the Whigs' election in Parliament

22 March $1831 \quad 6$ July $1831 \quad 20$ September $1831 \quad 17$ December 1831

\begin{tabular}{|c|c|c|c|c|c|}
\hline \multirow[t]{8}{*}{ Patronage } & \multirow[t]{2}{*}{ High influence } & -0.095 & -0.96 & -0.99 & -0.954 \\
\hline & & {$[0.230]$} & {$[0.260]^{* * *}$} & {$[0.265]^{* * *}$} & {$[0.269]^{* * *}$} \\
\hline & \multirow[t]{2}{*}{ Some influence } & -0.086 & -1.066 & -1.098 & -1.084 \\
\hline & & {$[0.206]$} & {$[0.242]^{* * *}$} & {$[0.247]^{* * *}$} & {$[0.252]^{* * *}$} \\
\hline & \multirow[t]{2}{*}{ No influence } & -0.136 & -0.679 & -0.704 & -0.675 \\
\hline & & {$[0.252]$} & {$[0.295]^{* *}$} & {$[0.301]^{* *}$} & {$[0.305]^{* *}$} \\
\hline & \multirow[t]{2}{*}{ Treasury borough } & 0.093 & -0.429 & -0.496 & -0.353 \\
\hline & & {$[0.328]$} & {$[0.365]$} & {$[0.370]$} & {$[0.374]$} \\
\hline \multirow{6}{*}{$\begin{array}{c}\text { Governance } \\
\text { structure }\end{array}$} & \multirow[t]{2}{*}{ Municipal corporation } & 9.056 & 14.928 & 15.258 & 13.207 \\
\hline & & {$[0.310]^{* * *}$} & {$[0.336]^{* * *}$} & {$[0.345]^{* * *}$} & {$[0.360]^{* * *}$} \\
\hline & \multirow[t]{2}{*}{ Representative borough } & 9.832 & 15.366 & 15.629 & 13.749 \\
\hline & & {$[0.337]^{* * *}$} & {$[0.380]^{* * *}$} & {$[0.388]^{* * *}$} & {$[0.397]^{* * *}$} \\
\hline & \multirow[t]{2}{*}{ County } & 9.877 & 16.224 & 16.43 & 14.605 \\
\hline & & {$[0.000]$} & {$[0.000]$} & {$[0.000]$} & {$[0.000]$} \\
\hline \multirow{12}{*}{$\begin{array}{c}\text { Franchise } \\
\text { type }\end{array}$} & \multirow[t]{2}{*}{ Burgage franchise } & -0.134 & -0.242 & -0.311 & -0.221 \\
\hline & & {$[0.262]$} & {$[0.281]$} & {$[0.285]$} & {$[0.295]$} \\
\hline & \multirow[t]{2}{*}{ Corporation franchise } & -0.274 & -0.655 & -0.761 & -0.618 \\
\hline & & {$[0.278]$} & {$[0.280]^{* *}$} & {$[0.288] * * *$} & {$[0.289]^{* *}$} \\
\hline & \multirow[t]{2}{*}{ Freeman franchise } & 0.011 & 0.069 & 0.011 & 0.121 \\
\hline & & {$[0.192]$} & {$[0.202]$} & {$[0.206]$} & {$[0.212]$} \\
\hline & \multirow[t]{2}{*}{ Scot and lot franchise. } & 0.194 & 0.625 & 0.52 & 0.607 \\
\hline & & {$[0.241]$} & {$[0.276]^{* *}$} & {$[0.284]^{*}$} & {$[0.288]^{* *}$} \\
\hline & \multirow[t]{2}{*}{ Freehold franchise } & -0.733 & 0.378 & 0.17 & 0.527 \\
\hline & & {$[0.421]^{*}$} & {$[0.451]$} & {$[0.474]$} & {$[0.462]$} \\
\hline & \multirow[t]{2}{*}{ Household franchise } & 0.451 & 5.286 & 5.268 & 5.311 \\
\hline & & {$[0.917]$} & {$[0.000]$} & {$[0.000]$} & {$[0.000]$} \\
\hline \multirow{4}{*}{$\begin{array}{c}\text { Economic } \\
\text { circumstances }\end{array}$} & \multirow[t]{2}{*}{ Thriving economy } & -0.116 & -0.321 & -0.407 & -0.287 \\
\hline & & {$[0.193]$} & {$[0.204]$} & {$[0.211]^{*}$} & {$[0.212]$} \\
\hline & \multirow[t]{2}{*}{ Declining economy } & 0.094 & -0.223 & -0.27 & -0.454 \\
\hline & & {$[0.222]$} & {$[0.227]$} & {$[0.232]$} & {$[0.256]^{*}$} \\
\hline \multirow{16}{*}{$\begin{array}{c}\text { Occupational } \\
\text { structure }\end{array}$} & \multirow[t]{2}{*}{$\begin{array}{l}\text { Landowners employing } \\
\text { workers }\end{array}$} & -14.55 & -0.494 & 2.163 & -10.082 \\
\hline & & {$[8.864]$} & [6.878] & {$[7.037]$} & {$[9.397]$} \\
\hline & \multirow[t]{2}{*}{$\begin{array}{l}\text { Landowners not } \\
\text { employing workers }\end{array}$} & -0.66 & -12.579 & -15.462 & -6.886 \\
\hline & & [7.069] & {$[6.331]^{* *}$} & {$[6.755]^{* *}$} & [7.352] \\
\hline & \multirow[t]{2}{*}{ Agricultural workers } & -0.258 & 3.823 & 4.244 & 3.942 \\
\hline & & [1.859] & {$[1.887]^{* *}$} & {$[1.938]^{* *}$} & {$[1.994]^{* *}$} \\
\hline & Industry workers & 0.186 & 3.815 & 4.327 & 3.121 \\
\hline & & {$[1.526]$} & {$[1.538]^{* *}$} & {$[1.581]^{* * *}$} & {$[1.585]^{* *}$} \\
\hline & Other workers & 0.78 & 2.538 & 2.954 & 1.974 \\
\hline & & {$[1.752]$} & {$[1.775]$} & [1.859] & [1.812] \\
\hline & Artisans & 0.144 & 4.473 & 4.817 & 3.722 \\
\hline & & {$[1.826]$} & {$[1.825]^{* *}$} & {$[1.887]^{* *}$} & {$[1.888]^{* *}$} \\
\hline & Professionals & 3.758 & 6.688 & 7.16 & 3.845 \\
\hline & & [4.549] & [4.654] & [4.769] & [4.828] \\
\hline & Male servants above 20 & 2.315 & 5.379 & 7.204 & 3.299 \\
\hline & & [7.288] & {$[7.856]$} & [8.114] & {$[8.537]$} \\
\hline
\end{tabular}

Continuing next page 


\begin{tabular}{clcccc}
$\begin{array}{c}\text { Political } \\
\text { circumstances }\end{array}$ & Contested seat & 0.097 & 0.001 & 0.025 & 0.024 \\
& & {$[0.187]$} & {$[0.198]$} & {$[0.203]$} & {$[0.205]$} \\
& Welsh borough & 0.261 & 0.413 & 0.26 & 0.125 \\
& & {$[0.366]$} & {$[0.365]$} & {$[0.394]$} & {$[0.399]$} \\
& Constant & -9.675 & -16.871 & -17.438 & -14.594 \\
& & {$[1.411]^{* * *}$} & {$[1.419]^{* * *}$} & {$[1.466]^{* * *}$} & {$[1.482]^{* * *}$} \\
& & & & 364 \\
& Observations & 392 & 391 & 146 & 146 \\
Non-censored & & & -0.005 \\
observations & 238 & 146 & 0.049 & {$[0.035]$} \\
& & -0.006 & 0.002 & {$[0.051]$} & 1653.304 \\
& {$[0.175]$} & {$[0.096]$} & 2124.297 & 0.000 \\
\hline
\end{tabular}

Notes:

- Standard errors are given in brackets.

- *** indicates significance at the $1 \%$-level, $* *$ indicates significance at the $5 \%$-level, * indicates significance at the $10 \%$-level. 
Table 5. Determinants of the Tories' election and opposition to reform: all the constituencies excluding the disenfranchised boroughs.

Vote equation of the Tory support for Reform

22 March $1831 \quad 6$ July $1831 \quad 20$ September $1831 \quad 17$ December 1831

\begin{tabular}{|c|c|c|c|c|c|}
\hline \multirow[t]{7}{*}{ Patronage } & High influence & $\begin{array}{c}0.175 \\
{[0.111]}\end{array}$ & $\begin{array}{c}0.152 \\
{[0.171]}\end{array}$ & $\begin{array}{c}0.368 \\
{[0.153]^{* *}}\end{array}$ & $\begin{array}{c}0.301 \\
{[0.169]^{*}}\end{array}$ \\
\hline & Some influence & 0.104 & 0.123 & 0.375 & 0.38 \\
\hline & & {$[0.104]$} & {$[0.173]$} & {$[0.153]^{* *}$} & {$[0.171]^{* *}$} \\
\hline & No influence & 0.009 & -0.018 & 0.237 & 0.227 \\
\hline & & {$[0.127]$} & {$[0.183]$} & {$[0.170]$} & {$[0.183]$} \\
\hline & Treasury borough & 0.47 & 0.209 & 0.442 & 0.279 \\
\hline & & {$[0.160]^{* * *}$} & [0.209] & {$[0.193]^{* *}$} & {$[0.219]$} \\
\hline \multirow{8}{*}{$\begin{array}{c}\text { Governance } \\
\text { structure }\end{array}$} & Municipal corporation & -0.81 & 0.084 & 0.033 & -0.148 \\
\hline & & [0.649] & [0.389] & {$[0.160]$} & {$[0.464]$} \\
\hline & Representative borough & -0.889 & -0.181 & & -0.374 \\
\hline & & {$[0.692]$} & {$[0.434]$} & & {$[0.513]$} \\
\hline & University & & & 0.245 & \\
\hline & & & & {$[0.415]$} & \\
\hline & County & -0.947 & -0.264 & -0.147 & -0.6 \\
\hline & & {$[0.634]$} & [0.417] & {$[0.188]$} & [0.494] \\
\hline \multirow[t]{12}{*}{ Franchise type } & Burgage franchise & -0.098 & -0.13 & -0.013 & -0.008 \\
\hline & & {$[0.127]$} & {$[0.138]$} & {$[0.136]$} & {$[0.162]$} \\
\hline & Corporation franchise & 0.071 & -0.173 & 0.031 & -0.011 \\
\hline & & {$[0.130]$} & {$[0.136]$} & [0.129] & {$[0.147]$} \\
\hline & Freeman franchise & 0.025 & -0.157 & 0.041 & 0.038 \\
\hline & & {$[0.090]$} & [0.109] & {$[0.102]$} & {$[0.121]$} \\
\hline & Scot and lot franchise. & 0.161 & -0.204 & -0.053 & -0.205 \\
\hline & & {$[0.122]$} & {$[0.165]$} & {$[0.151]$} & {$[0.166]$} \\
\hline & Freehold franchise. & 0.146 & -0.728 & -0.154 & -0.65 \\
\hline & & {$[0.176]$} & {$[0.369]^{* *}$} & [0.349] & {$[0.382]^{*}$} \\
\hline & Household franchise & -0.52 & & & \\
\hline & & {$[0.482]$} & & & \\
\hline \multirow{14}{*}{$\begin{array}{l}\text { MPs' occupations } \\
\text { \& characteristics }\end{array}$} & Army career & 0.008 & -0.144 & -0.134 & 0.022 \\
\hline & & {$[0.095]$} & [0.104] & [0.103] & [0.107] \\
\hline & Financiers & 0.157 & -0.477 & -0.458 & -0.569 \\
\hline & & {$[0.160]$} & {$[0.174] * * *$} & {$[0.175]^{* * *}$} & {$[0.209]^{* * *}$} \\
\hline & Dynasty heir & -0.077 & -0.016 & 0.058 & 0.177 \\
\hline & & {$[0.079]$} & {$[0.103]$} & [0.099] & {$[0.106]^{*}$} \\
\hline & Industrialist & -0.16 & -0.229 & 0.082 & -0.352 \\
\hline & & {$[0.157]$} & [0.199] & {$[0.208]$} & {$[0.255]$} \\
\hline & Jurist & 0.014 & 0.06 & 0.016 & 0.166 \\
\hline & & {$[0.108]$} & {$[0.112]$} & [0.109] & {$[0.116]$} \\
\hline & Merchant & 0.087 & 0.24 & 0.171 & 0.073 \\
\hline & & {$[0.127]$} & [0.161] & {$[0.160]$} & {$[0.207]$} \\
\hline & Relatives in Parliament & 0.114 & 0.15 & 0.18 & 0.101 \\
\hline & & {$[0.075]$} & {$[0.081]^{*}$} & {$[0.079] * *$} & {$[0.079]$} \\
\hline \multirow{6}{*}{$\begin{array}{c}\text { Political } \\
\text { circumstances }\end{array}$} & $\begin{array}{l}\text { Uncontested seat } \\
(1800-1831)\end{array}$ & 0.066 & 0.03 & -0.082 & 0.007 \\
\hline & & {$[0.092]$} & {$[0.100]$} & [0.099] & {$[0.103]$} \\
\hline & Seats after Reform & & 0.266 & 0.168 & 0.352 \\
\hline & & & {$[0.130]^{* *}$} & {$[0.125]$} & {$[0.141]^{* *}$} \\
\hline & Constant & 1.445 & 0.327 & 0.21 & 0.018 \\
\hline & & {$[0.596]^{* *}$} & {$[0.407]$} & {$[0.363]$} & {$[0.483]$} \\
\hline
\end{tabular}

Continuing next page 
Party affiliation equation of the Tories' election in Parliament

22 March $1831 \quad 6$ July $1831 \quad 20$ September 1831

17 December 1831

\begin{tabular}{|c|c|c|c|c|c|}
\hline \multirow[t]{8}{*}{ Patronage } & \multirow[t]{2}{*}{ High influence } & 0.151 & 1.05 & 0.915 & 0.848 \\
\hline & & {$[0.228]$} & {$[0.270]^{* * *}$} & {$[0.264]^{* * *}$} & {$[0.286]^{* * *}$} \\
\hline & \multirow[t]{2}{*}{ Some influence } & 0.118 & 1.155 & 1.021 & 1.046 \\
\hline & & {$[0.204]$} & {$[0.252]^{* * *}$} & {$[0.243]^{* * *}$} & {$[0.263]^{* * *}$} \\
\hline & \multirow[t]{2}{*}{ No influence } & 0.224 & 0.799 & 0.587 & 0.711 \\
\hline & & {$[0.250]$} & {$[0.303]^{* * *}$} & {$[0.301]^{*}$} & {$[0.320]^{* *}$} \\
\hline & \multirow[t]{2}{*}{ Treasury borough } & -0.016 & 0.547 & 0.374 & 0.51 \\
\hline & & [0.329] & [0.369] & {$[0.371]$} & {$[0.419]$} \\
\hline \multirow{6}{*}{$\begin{array}{c}\text { Governance } \\
\text { structure }\end{array}$} & \multirow[t]{2}{*}{ Municipal corporation } & -8.778 & -14.634 & -15.354 & -15.675 \\
\hline & & {$[0.306]^{* * *}$} & {$[0.340]^{* * *}$} & {$[0.291]^{* * *}$} & {$[0.302]^{* * *}$} \\
\hline & \multirow[t]{2}{*}{ Representative borough } & -9.466 & -15.125 & -15.91 & -16.175 \\
\hline & & {$[0.339]^{* * *}$} & {$[0.384]^{* * *}$} & {$[0.000]$} & {$[0.000]$} \\
\hline & \multirow[t]{2}{*}{ County } & -9.491 & -15.995 & -16.628 & -16.999 \\
\hline & & {$[0.000]$} & {$[0.000]$} & {$[0.398]^{* * *}$} & {$[0.437]^{* * *}$} \\
\hline \multirow[t]{12}{*}{ Franchise type } & \multirow[t]{2}{*}{ Burgage franchise } & 0.132 & 0.315 & 0.35 & 0.517 \\
\hline & & {$[0.268]$} & {$[0.284]$} & {$[0.287]$} & {$[0.311]^{*}$} \\
\hline & \multirow[t]{2}{*}{ Corporation franchise } & 0.272 & 0.672 & 0.629 & 0.866 \\
\hline & & {$[0.276]$} & {$[0.287]^{* *}$} & {$[0.289]^{* *}$} & {$[0.306] * * *$} \\
\hline & \multirow[t]{2}{*}{ Freeman franchise } & 0.031 & -0.041 & -0.049 & -0.022 \\
\hline & & [0.191] & {$[0.202]$} & {$[0.206]$} & {$[0.227]$} \\
\hline & \multirow[t]{2}{*}{ Scot and lot franchise. } & -0.14 & -0.639 & -0.565 & -0.48 \\
\hline & & {$[0.242]$} & {$[0.279]^{* *}$} & {$[0.281]^{* *}$} & {$[0.307]$} \\
\hline & \multirow[t]{2}{*}{ Freehold franchise } & 0.712 & -0.637 & -0.521 & -0.326 \\
\hline & & {$[0.431]^{*}$} & [0.496] & {$[0.493]$} & {$[0.510]$} \\
\hline & \multirow[t]{2}{*}{ Household franchise } & -0.398 & -5.292 & -5.269 & -5.246 \\
\hline & & {$[0.918]$} & {$[0.000]$} & {$[0.000]$} & {$[0.000]$} \\
\hline \multirow{4}{*}{$\begin{array}{c}\text { Economic } \\
\text { circumstances }\end{array}$} & \multirow[t]{2}{*}{ Thriving economy } & 0.11 & 0.422 & 0.425 & 0.577 \\
\hline & & {$[0.194]$} & {$[0.206]^{* *}$} & {$[0.207]^{* *}$} & {$[0.221]^{* * *}$} \\
\hline & \multirow[t]{2}{*}{ Declining economy } & -0.066 & 0.18 & 0.091 & 0.147 \\
\hline & & {$[0.227]$} & {$[0.229]$} & {$[0.239]$} & {$[0.250]$} \\
\hline \multirow{19}{*}{$\begin{array}{c}\text { Occupational } \\
\text { structure }\end{array}$} & \multirow[t]{2}{*}{$\begin{array}{l}\text { Landowners employing } \\
\text { workers }\end{array}$} & 14.211 & 2.948 & 1.466 & -0.218 \\
\hline & & {$[9.292]$} & [6.942] & {$[6.886]$} & {$[7.621]$} \\
\hline & $\begin{array}{l}\text { Landowners not } \\
\text { employing workers }\end{array}$ & -0.635 & 13.977 & 9.759 & 11.296 \\
\hline & & {$[7.262]$} & {$[6.417]^{* *}$} & {$[6.528]$} & [7.323] \\
\hline & Agricultural workers & 0.248 & -3.807 & -3.987 & -1.721 \\
\hline & & {$[1.937]$} & {$[1.916]^{* *}$} & {$[1.951]^{* *}$} & [2.716] \\
\hline & Industry workers & -0.423 & -3.803 & -3.947 & -2.007 \\
\hline & & {$[1.565]$} & {$[1.560]^{* *}$} & {$[1.559]^{* *}$} & {$[2.367]$} \\
\hline & Other workers & -0.334 & -2.484 & -2.916 & -2.77 \\
\hline & & {$[1.848]$} & [1.799] & [1.811] & {$[2.468]$} \\
\hline & Artisans & -0.522 & -4.532 & -4.931 & -2.922 \\
\hline & & [1.985] & {$[1.859]^{* *}$} & {$[1.867]^{* * *}$} & {$[2.405]$} \\
\hline & Professionals & -3.2 & -6.048 & -7.679 & -5.891 \\
\hline & & [4.633] & {$[4.745]$} & [4.777] & {$[5.158]$} \\
\hline & Male servants above 20 & -3.213 & -4.793 & -5.086 & -8.502 \\
\hline & & {$[7.646]$} & {$[8.070]$} & {$[8.218]$} & {$[9.369]$} \\
\hline & Male servants below 20 & & & & 19.134 \\
\hline & & & & & [11.917] \\
\hline & Female servants & & & & 3.215 \\
\hline Continuing next & & & & & {$[3.583]$} \\
\hline
\end{tabular}




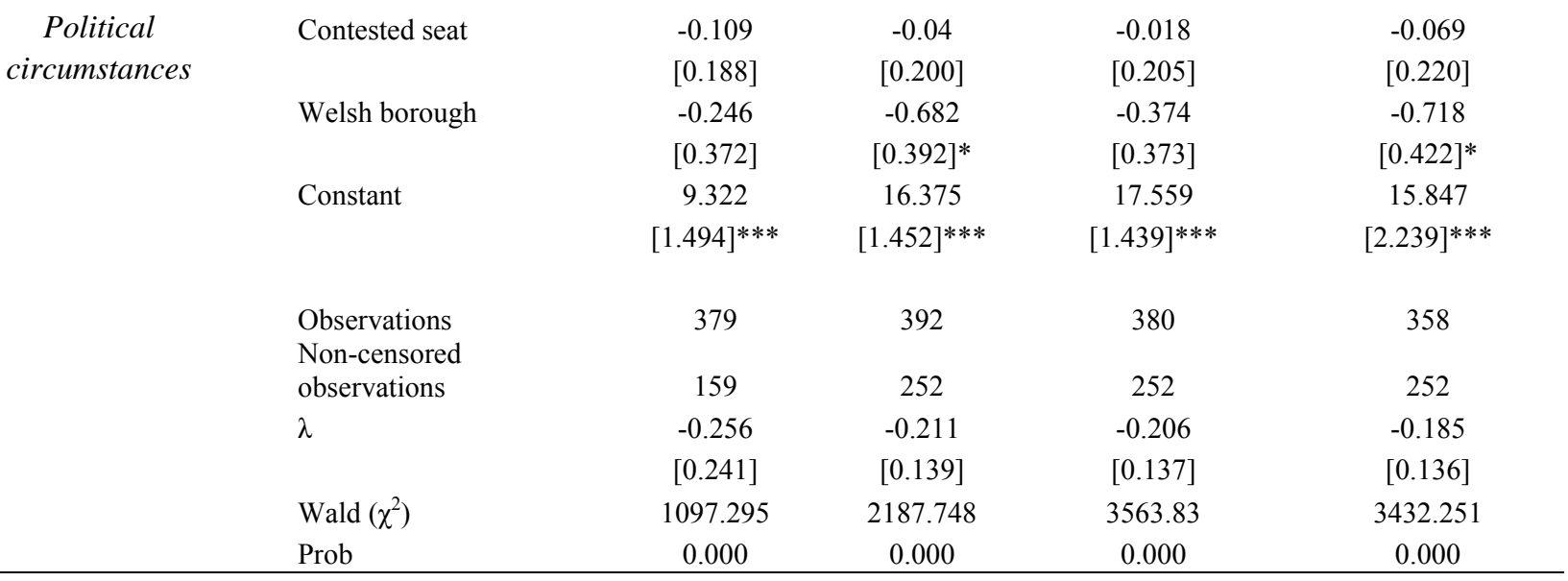

Notes:

- Standard errors are given in brackets.

- *** indicates significance at the $1 \%$-level, $* *$ indicates significance at the $5 \%$-level, * indicates significance at the $10 \%$-level. 
Table A1. Descriptive statistics

\section{Explanatory variables} Governance structure

MPs' occupations

\& attributes in 1830

MPs' occupations

\& attributes in 1831

Patronage

Occupational structure
Municipal corporation

Representative borough

University seat

County

Burgage franchise

Corporation franchise

Freeman franchise

Potwalloper franchise

Scot and lot franchise.

Freehold franchise.

County franchise

Household franchise

Army career

Financiers

Dynasty heir

Industrialist

Jurist

Merchant

Landowner

Relatives in Parliament

Army career

Financiers

Dynasty heir

Industrialist

Jurist

Merchant

Landowner

Relatives in Parliament

Thriving economy

Declining economy

High influence

Some influence

Low influence

No influence

Treasury borough

Landowners employing workers

Landowners not employing workers

Agricultural workers

Industry workers

Other workers

Artisans

Professionals

Unknown professions

Male servants above 20

Male servants below 20

Female servants

\begin{tabular}{|c|c|c|c|c|}
\hline Obs & Mean & Std Dv. & Min & Max \\
\hline 511 & 0.618 & 0.486 & 0 & 1 \\
\hline 511 & 0.192 & 0.394 & 0 & 1 \\
\hline 511 & 0.004 & 0.062 & 0 & 1 \\
\hline 511 & 0.186 & 0.389 & 0 & 1 \\
\hline 511 & 0.137 & 0.344 & 0 & 1 \\
\hline 511 & 0.108 & 0.310 & 0 & 1 \\
\hline 511 & 0.327 & 0.470 & 0 & 1 \\
\hline 511 & 0.051 & 0.220 & 0 & 1 \\
\hline 511 & 0.174 & 0.380 & 0 & 1 \\
\hline 511 & 0.027 & 0.163 & 0 & 1 \\
\hline 511 & 0.168 & 0.374 & 0 & 1 \\
\hline 511 & 0.008 & 0.088 & 0 & 1 \\
\hline 513 & 0.191 & 0.393 & 0 & 1 \\
\hline 513 & 0.057 & 0.231 & 0 & 1 \\
\hline 513 & 0.413 & 0.493 & 0 & 1 \\
\hline 513 & 0.049 & 0.216 & 0 & 1 \\
\hline 513 & 0.129 & 0.335 & 0 & 1 \\
\hline 513 & 0.086 & 0.280 & 0 & 1 \\
\hline 513 & 0.454 & 0.498 & 0 & 1 \\
\hline 505 & 0.624 & 0.485 & 0 & 1 \\
\hline 513 & 0.185 & 0.389 & 0 & 1 \\
\hline 513 & 0.070 & 0.256 & 0 & 1 \\
\hline 513 & 0.349 & 0.477 & 0 & 1 \\
\hline 513 & 0.041 & 0.198 & 0 & 1 \\
\hline 513 & 0.148 & 0.356 & 0 & 1 \\
\hline 513 & 0.076 & 0.265 & 0 & 1 \\
\hline 513 & 0.380 & 0.486 & 0 & 1 \\
\hline 506 & 0.625 & 0.485 & 0 & 1 \\
\hline 513 & 0.177 & 0.382 & 0 & 1 \\
\hline 513 & 0.199 & 0.400 & 0 & 1 \\
\hline 511 & 0.333 & 0.472 & 0 & 1 \\
\hline 511 & 0.362 & 0.481 & 0 & 1 \\
\hline 511 & 0.151 & 0.358 & 0 & 1 \\
\hline 511 & 0.100 & 0.300 & 0 & 1 \\
\hline 511 & 0.055 & 0.228 & 0 & 1 \\
\hline 513 & 0.026 & 0.032 & 0 & 0.250 \\
\hline 513 & 0.016 & 0.023 & 0 & 0.138 \\
\hline 513 & 0.153 & 0.150 & 0 & 0.769 \\
\hline 513 & 0.042 & 0.090 & 0 & 0.498 \\
\hline 513 & 0.324 & 0.113 & 0 & 0.872 \\
\hline 513 & 0.056 & 0.050 & 0 & 0.735 \\
\hline 513 & 0.136 & 0.085 & 0 & 0.589 \\
\hline 513 & 0.101 & 2.665 & 0 & 0.225 \\
\hline 513 & 0.377 & 1.437 & 0 & 0.580 \\
\hline 513 & 0.158 & 0.477 & 0 & 0.592 \\
\hline 513 & 0.281 & 0.785 & 0 & 0.554 \\
\hline
\end{tabular}

Continuing next page 
Disenfranchised borough

English borough

Welsh borough

Contested seat

Uncontested seat (1800-1831)

Seats after Reform
513

Tory opposition to the Reform on 20 September 1831

Tory opposition to the Reform on 6 July 1831

$\begin{array}{ll}0 & 1 \\ 0 & 1 \\ 0 & 1 \\ 0 & 1 \\ 0 & 1 \\ 1 & 4\end{array}$


Table A2. Determinants of the Whigs' election and support for reform: all the constituencies.

\section{Vote equation of the Whig support for Reform}

22 March 1831

\begin{tabular}{|c|c|c|c|c|c|}
\hline \multirow[t]{7}{*}{ Patronage } & High influence & $\begin{array}{c}-0.043 \\
{[0.103]}\end{array}$ & $\begin{array}{c}0.023 \\
{[0.059]}\end{array}$ & $\begin{array}{c}0.002 \\
{[0.033]}\end{array}$ & $\begin{array}{c}0.031 \\
{[0.022]}\end{array}$ \\
\hline & Some influence & -0.04 & 0.01 & 0.017 & 0.036 \\
\hline & & {$[0.086]$} & {$[0.053]$} & {$[0.029]$} & {$[0.019]^{*}$} \\
\hline & No influence & 0.203 & 0.018 & 0.034 & 0.04 \\
\hline & & {$[0.110]^{*}$} & {$[0.056]$} & {$[0.031]$} & {$[0.020]^{* *}$} \\
\hline & Treasury borough & -0.117 & 0.088 & 0.027 & 0.029 \\
\hline & & {$[0.133]$} & {$[0.074]$} & {$[0.041]$} & {$[0.026]$} \\
\hline \multirow{6}{*}{$\begin{array}{c}\text { Governance } \\
\text { structure }\end{array}$} & Municipal corporation & 0.04 & -0.013 & 0.077 & -0.007 \\
\hline & & {$[0.084]$} & {$[0.048]$} & {$[0.027]^{* * *}$} & {$[0.018]$} \\
\hline & Representative borough & & -0.125 & & -0.075 \\
\hline & & & {$[0.060]^{* *}$} & & {$[0.021]^{* * *}$} \\
\hline & County & 0.153 & & 0.093 & \\
\hline & & {$[0.103]$} & & {$[0.034]^{* * *}$} & \\
\hline \multirow{12}{*}{$\begin{array}{c}\text { Franchise } \\
\text { type }\end{array}$} & Burgage franchise & 0.081 & -0.154 & -0.023 & 0.001 \\
\hline & & {$[0.106]$} & {$[0.058]^{* * *}$} & {$[0.032]$} & {$[0.021]$} \\
\hline & Corporation franchise & 0.308 & 0.045 & -0.027 & 0.024 \\
\hline & & {$[0.133]^{* *}$} & {$[0.075]$} & {$[0.042]$} & {$[0.027]$} \\
\hline & Freeman franchise & 0.172 & 0.007 & -0.016 & -0.012 \\
\hline & & {$[0.082]^{* *}$} & {$[0.042]$} & {$[0.023]$} & {$[0.015]$} \\
\hline & Scot and lot franchise. & 0.015 & 0.044 & 0.026 & 0.015 \\
\hline & & {$[0.094]$} & {$[0.050]$} & {$[0.028]$} & {$[0.018]$} \\
\hline & Freehold franchise. & 0.265 & 0.042 & -0.01 & -0.006 \\
\hline & & {$[0.232]$} & [0.089] & {$[0.054]$} & {$[0.031]$} \\
\hline & Household franchise & 0.221 & 0.028 & 0.004 & -0.004 \\
\hline & & {$[0.375]$} & {$[0.181]$} & [0.099] & {$[0.062]$} \\
\hline \multirow{14}{*}{$\begin{array}{c}\text { MPs' } \\
\text { occupations } \\
\text { \& attributes }\end{array}$} & Army career & -0.209 & 0.033 & 0.012 & 0.012 \\
\hline & & {$[0.092]^{* *}$} & {$[0.053]$} & {$[0.030]$} & {$[0.019]$} \\
\hline & Financiers & -0.167 & 0.029 & 0.041 & 0.019 \\
\hline & & {$[0.103]$} & {$[0.056]$} & {$[0.031]$} & {$[0.021]$} \\
\hline & Dynasty heir & -0.114 & 0.053 & 0.029 & 0.005 \\
\hline & & {$[0.074]$} & {$[0.041]$} & {$[0.023]$} & {$[0.015]$} \\
\hline & Industrialist & -0.095 & -0.091 & -0.068 & -0.087 \\
\hline & & {$[0.101]$} & {$[0.073]$} & {$[0.042]$} & {$[0.027]^{* * *}$} \\
\hline & Jurist & -0.249 & 0.026 & 0 & 0.01 \\
\hline & & {$[0.117]^{* *}$} & {$[0.051]$} & {$[0.028]$} & {$[0.018]$} \\
\hline & Merchant & 0.028 & -0.016 & 0.016 & 0.01 \\
\hline & & {$[0.105]$} & {$[0.062]$} & {$[0.037]$} & {$[0.022]$} \\
\hline & Relatives in Parliament & -0.04 & 0.011 & -0.03 & -0.012 \\
\hline & & {$[0.064]$} & {$[0.034]$} & [0.019] & {$[0.013]$} \\
\hline \multirow{6}{*}{$\begin{array}{c}\text { Political } \\
\text { circumstances }\end{array}$} & $\begin{array}{l}\text { Uncontested seat } \\
(1800-1831)\end{array}$ & 0.139 & 0.012 & 0.023 & 0.018 \\
\hline & & {$[0.086]$} & {$[0.046]$} & {$[0.027]$} & {$[0.017]$} \\
\hline & Seats after Reform & & 0.027 & 0.037 & 0.012 \\
\hline & & & {$[0.039]$} & {$[0.024]$} & {$[0.015]$} \\
\hline & Constant & 0.912 & 0.876 & 0.811 & 0.947 \\
\hline & & {$[0.194]^{* * *}$} & {$[0.107]^{* * *}$} & {$[0.071]^{* * *}$} & {$[0.039]^{* * *}$} \\
\hline
\end{tabular}

6 July 1831

20 September 1831

17 December 1831

$-0.043$

0.086

110]*

$-0.117$

0.04

0.081

$[0.133]^{* *}$

0.015

0.094

[0.232]

0.221

$-0.209$

$-0.167$

0.103

$-0.114$

$-0.095$

$-0.249$

0.028

$[0.105]$

0.139
$[0.107]^{* * *}$

$[0.071]^{* * *}$

\footnotetext{
Continuing next page
} 
Party affiliation equation of the Whigs' election in Parliament

22 March $1831 \quad 6$ July $1831 \quad 20$ September $1831 \quad 17$ December 1831

\begin{tabular}{|c|c|c|c|c|c|}
\hline \multirow[t]{7}{*}{ Patronage } & High influence & $\begin{array}{c}-0.116 \\
{[0.208]}\end{array}$ & $\begin{array}{c}-0.791 \\
{[0.229]^{* * *}}\end{array}$ & $\begin{array}{c}-0.798 \\
{[0.233]^{* * *}}\end{array}$ & $\begin{array}{c}-0.818 \\
{[0.237]^{* * *}}\end{array}$ \\
\hline & Some influence & -0.079 & -0.8 & -0.801 & -0.815 \\
\hline & & {$[0.192]$} & {$[0.216]^{* * *}$} & {$[0.219]^{* * *}$} & {$[0.223]^{* * *}$} \\
\hline & No influence & -0.06 & -0.45 & -0.457 & -0.448 \\
\hline & & {$[0.242]$} & {$[0.275]$} & {$[0.279]$} & {$[0.284]$} \\
\hline & Treasury borough & 0.109 & -0.558 & -0.6 & -0.48 \\
\hline & & {$[0.313]$} & {$[0.340]$} & {$[0.344]^{*}$} & [0.349] \\
\hline \multirow{6}{*}{$\begin{array}{c}\text { Governance } \\
\text { structure }\end{array}$} & Municipal corporation & 8.778 & 11.72 & 11.755 & 9.922 \\
\hline & & {$[0.185]^{* * *}$} & {$[0.198]^{* * *}$} & {$[0.288]^{* * *}$} & {$[0.291]^{* * *}$} \\
\hline & Representative borough & 8.983 & 11.714 & 11.819 & 9.934 \\
\hline & & {$[0.000]$} & {$[0.000]$} & {$[0.321]^{* * *}$} & {$[0.321]^{* * *}$} \\
\hline & County & 8.993 & 12.769 & 12.806 & 10.987 \\
\hline & & {$[0.270]^{* * *}$} & {$[0.312]^{* * *}$} & {$[0.000]$} & {$[0.000]$} \\
\hline \multirow{12}{*}{$\begin{array}{c}\text { Franchise } \\
\text { type }\end{array}$} & Burgage franchise & 0.05 & -0.007 & -0.098 & 0.066 \\
\hline & & {$[0.225]$} & {$[0.240]$} & {$[0.246]$} & [0.249] \\
\hline & Corporation franchise & -0.334 & -0.512 & -0.562 & -0.51 \\
\hline & & {$[0.244]$} & {$[0.251]^{* *}$} & {$[0.258]^{* *}$} & {$[0.258]^{* *}$} \\
\hline & Freeman franchise & -0.028 & 0.107 & 0.109 & 0.174 \\
\hline & & {$[0.176]$} & {$[0.186]$} & {$[0.190]$} & {$[0.193]$} \\
\hline & Scot and lot franchise. & 0.347 & 0.332 & 0.262 & 0.32 \\
\hline & & {$[0.202]^{*}$} & {$[0.223]$} & {$[0.230]$} & {$[0.232]$} \\
\hline & Freehold franchise & -0.638 & 0.437 & 0.2 & 0.6 \\
\hline & & {$[0.408]$} & {$[0.443]$} & {$[0.468]$} & {$[0.455]$} \\
\hline & Household franchise & 0.211 & 5.339 & 5.306 & 5.355 \\
\hline & & [0.912] & {$[0.000]$} & {$[0.000]$} & {$[0.000]$} \\
\hline \multirow{4}{*}{$\begin{array}{c}\text { Economic } \\
\text { circumstances }\end{array}$} & Thriving economy & -0.003 & -0.398 & -0.474 & -0.337 \\
\hline & & {$[0.176]$} & {$[0.185]^{* *}$} & {$[0.192]^{* *}$} & {$[0.191]^{*}$} \\
\hline & Declining economy & 0.19 & -0.359 & -0.385 & -0.479 \\
\hline & & {$[0.168]$} & {$[0.176]^{* *}$} & {$[0.180]^{* *}$} & {$[0.190]^{* *}$} \\
\hline \multirow{16}{*}{$\begin{array}{l}\text { Occupational } \\
\text { structure }\end{array}$} & Landowners employing workers & -3.607 & -4.115 & -3.117 & -6.585 \\
\hline & & {$[3.473]$} & {$[4.068]$} & [4.109] & [4.821] \\
\hline & Landowners not employing workers & -1.661 & -10.57 & -13.181 & -8.079 \\
\hline & & {$[4.202]$} & {$[4.910]^{* *}$} & {$[5.300]^{* *}$} & {$[5.198]$} \\
\hline & Agricultural workers & 1.165 & 1.55 & 2.045 & 1.449 \\
\hline & & [1.336] & [1.385] & {$[1.422]$} & {$[1.428]$} \\
\hline & Industry workers & 0.178 & 1.16 & 1.685 & 0.74 \\
\hline & & {$[1.262]$} & {$[1.275]$} & [1.299] & [1.307] \\
\hline & Other workers & -0.57 & 1.438 & 2.11 & 1.051 \\
\hline & & [1.383] & {$[1.353]$} & [1.394] & [1.383] \\
\hline & Artisans & 1.062 & 1.678 & 2.081 & 1.281 \\
\hline & & {$[1.437]$} & [1.459] & [1.492] & {$[1.508]$} \\
\hline & Professionals & 5.304 & 0.937 & 1.271 & -1.729 \\
\hline & & {$[3.579]$} & {$[3.657]$} & [3.749] & [3.791] \\
\hline & Male servants above 20 & -5.316 & -3.625 & -2.577 & -5.366 \\
\hline & & {$[5.718]$} & [6.019] & [6.167] & {$[6.554]$} \\
\hline
\end{tabular}

Continuing next page 


\begin{tabular}{|c|c|c|c|c|c|}
\hline $\begin{array}{c}\text { Political } \\
\text { circumstances }\end{array}$ & Disenfranchised borough & $\begin{array}{c}-0.492 \\
{[0.214]^{* *}}\end{array}$ & $\begin{array}{c}-0.751 \\
{[0.219]^{* * *}}\end{array}$ & $\begin{array}{c}-0.81 \\
{[0.226]^{* * *}}\end{array}$ & $\begin{array}{c}-0.664 \\
{[0.226]^{* * *}}\end{array}$ \\
\hline & Contested seat & $\begin{array}{c}0.035 \\
{[0.161]}\end{array}$ & $\begin{array}{c}-0.092 \\
{[0.168]}\end{array}$ & $\begin{array}{c}0.004 \\
{[0.173]}\end{array}$ & $\begin{array}{c}-0.048 \\
{[0.172]}\end{array}$ \\
\hline & Welsh borough & $\begin{array}{c}0.055 \\
{[0.331]}\end{array}$ & $\begin{array}{c}0.016 \\
{[0.335]}\end{array}$ & $\begin{array}{c}-0.102 \\
{[0.366]}\end{array}$ & $\begin{array}{c}-0.321 \\
{[0.367]}\end{array}$ \\
\hline & Constant & $\begin{array}{c}-9.634 \\
{[1.116]^{* * *}}\end{array}$ & $\begin{array}{c}-11.581 \\
{[1.138]^{* * *}}\end{array}$ & $\begin{array}{c}-12.014 \\
{[1.165]^{* * *}}\end{array}$ & $\begin{array}{c}-9.487 \\
{[1.175]^{* * *}}\end{array}$ \\
\hline & Observations & 503 & 501 & 485 & 473 \\
\hline & Non-censored observations & 320 & 232 & 232 & 232 \\
\hline & $\lambda$ & $\begin{array}{c}-0.114 \\
{[0.184]}\end{array}$ & $\begin{array}{l}-0.045 \\
{[0.069]}\end{array}$ & $\begin{array}{c}0.026 \\
{[0.037]}\end{array}$ & $\begin{array}{c}0.013 \\
{[0.024]}\end{array}$ \\
\hline & Wald $\left(\chi^{2}\right)$ & 2576.079 & 3792.074 & 1880.414 & 1429.68 \\
\hline & Prob & 0.000 & 0.000 & 0.000 & 0.000 \\
\hline
\end{tabular}

Notes:

- Standard errors are given in brackets.

- *** indicates significance at the $1 \%$-level, ** indicates significance at the $5 \%$-level, $*$ indicates significance at the 10\%-level. 
Table A3. Determinants of the Whigs' election and opposition to reform: the disenfranchised boroughs.

\section{Vote equation of the Whig support for Reform}

22 March $1831 \quad 6$ July 1831

20 September 1831

\begin{tabular}{|c|c|c|c|c|}
\hline \multirow[t]{4}{*}{ Patronage } & High influence & $\begin{array}{c}0.161 \\
{[0.182]}\end{array}$ & & $\begin{array}{l}-0.169 \\
{[0.155]}\end{array}$ \\
\hline & Some influence & $\begin{array}{c}-0.063 \\
{[0.161]}\end{array}$ & $\begin{array}{c}-0.18 \\
{[0.280]}\end{array}$ & \\
\hline & No influence & $\begin{array}{c}0.168 \\
{[0.288]}\end{array}$ & & \\
\hline & Treasury borough & $\begin{array}{c}0.442 \\
{[0.399]}\end{array}$ & & \\
\hline \multirow[t]{3}{*}{$\begin{array}{c}\text { Governance } \\
\text { structure }\end{array}$} & Municipal corporation & $\begin{array}{c}0.638 \\
{[0.270]^{* *}}\end{array}$ & $\begin{array}{c}0.275 \\
{[0.187]}\end{array}$ & \\
\hline & Representative borough & $\begin{array}{c}0.247 \\
{[0.314]}\end{array}$ & & $\begin{array}{c}-0.365 \\
{[0.113]^{* * *}}\end{array}$ \\
\hline & University & $\begin{array}{c}0.26 \\
{[0.173]}\end{array}$ & & \\
\hline \multirow[t]{4}{*}{ Franchise type } & Burgage franchise & & $\begin{array}{l}-0.771 \\
{[0.575]}\end{array}$ & $\begin{array}{c}0.478 \\
{[0.127]^{* * *}}\end{array}$ \\
\hline & Corporation franchise & & $\begin{array}{c}-0.97 \\
{[0.566]^{*}}\end{array}$ & \\
\hline & Freeman franchise & & $\begin{array}{c}-0.34 \\
{[0.545]}\end{array}$ & $\begin{array}{c}0.546 \\
{[0.125]^{* * *}}\end{array}$ \\
\hline & Scot and lot franchise. & & $\begin{array}{l}-0.339 \\
{[0.615]}\end{array}$ & $\begin{array}{c}0.654 \\
{[0.151]^{* * *}}\end{array}$ \\
\hline \multirow[t]{7}{*}{$\begin{array}{l}\text { MPs' occupations } \\
\text { \& characteristics }\end{array}$} & Army career & $\begin{array}{c}0.397 \\
{[0.346]}\end{array}$ & $\begin{array}{c}-0.488 \\
{[0.264]^{*}}\end{array}$ & $\begin{array}{c}-0.123 \\
{[0.127]}\end{array}$ \\
\hline & Financiers & $\begin{array}{c}-0.468 \\
{[0.256]^{*}}\end{array}$ & $\begin{array}{c}-0.44 \\
{[0.279]}\end{array}$ & $\begin{array}{l}-0.084 \\
{[0.213]}\end{array}$ \\
\hline & Dynasty heir & $\begin{array}{c}-0.174 \\
{[0.309]}\end{array}$ & $\begin{array}{c}0.2 \\
{[0.260]}\end{array}$ & $\begin{array}{c}0.15 \\
{[0.097]}\end{array}$ \\
\hline & Industrialist & $\begin{array}{c}-0.386 \\
{[0.596]}\end{array}$ & & \\
\hline & Jurist & $\begin{array}{c}-0.409 \\
{[0.234]^{*}}\end{array}$ & $\begin{array}{c}-0.148 \\
{[0.229]}\end{array}$ & $\begin{array}{c}-0.15 \\
{[0.095]}\end{array}$ \\
\hline & Merchant & $\begin{array}{c}0.303 \\
{[0.374]}\end{array}$ & & \\
\hline & Relatives in Parliament & $\begin{array}{c}-0.174 \\
{[0.316]}\end{array}$ & $\begin{array}{c}0.206 \\
{[0.188]}\end{array}$ & $\begin{array}{c}0.043 \\
{[0.083]}\end{array}$ \\
\hline \multirow[t]{2}{*}{$\begin{array}{c}\text { Political } \\
\text { circumstances }\end{array}$} & Uncontested seat $(1800-1831)$ & & $\begin{array}{l}-0.011 \\
{[0.322]}\end{array}$ & $\begin{array}{c}0.28 \\
{[0.167]^{*}}\end{array}$ \\
\hline & Constant & $\begin{array}{c}0.543 \\
{[0.455]}\end{array}$ & $\begin{array}{c}1.392 \\
{[0.917]}\end{array}$ & $\begin{array}{c}0.804 \\
{[0.169]^{* * *}}\end{array}$ \\
\hline
\end{tabular}

Continuing next page 
Party affiliation equation of the Whigs' election in Parliament

\begin{tabular}{|c|c|c|c|c|}
\hline & & 22 March 1831 & 6 July 1831 & 20 September 1831 \\
\hline \multirow[t]{6}{*}{ Patronage } & High influence & 7.898 & 5.491 & 5.799 \\
\hline & & {$[0.344]^{* * *}$} & {$[0.373]^{* * *}$} & {$[0.403]^{* * *}$} \\
\hline & Some influence & 7.87 & 5.785 & 5.998 \\
\hline & & {$[0.000]$} & {$[0.000]$} & {$[0.000]$} \\
\hline & Treasury borough & 3.457 & 0.462 & 0.094 \\
\hline & & {$[0.000]$} & {$[0.000]$} & {$[0.000]$} \\
\hline \multirow{4}{*}{$\begin{array}{c}\text { Governance } \\
\text { structure }\end{array}$} & Municipal corporation & 0.144 & & -0.081 \\
\hline & & {$[0.361]$} & & {$[0.379]$} \\
\hline & Representative borough & & -0.287 & \\
\hline & & & {$[0.367]$} & \\
\hline \multirow[t]{8}{*}{ Franchise type } & Burgage franchise & 0.215 & 1.175 & 6.78 \\
\hline & & {$[0.587]$} & {$[0.734]$} & {$[0.000]$} \\
\hline & Corporation franchise & -0.456 & 0.204 & 6.009 \\
\hline & & [0.707] & [0.804] & {$[0.640]^{* * *}$} \\
\hline & Freeman franchise & -0.307 & 0.423 & 6.359 \\
\hline & & {$[0.531]$} & [0.699] & {$[0.490]^{* * *}$} \\
\hline & Scot and lot franchise. & 0.265 & 0.817 & 6.414 \\
\hline & & {$[0.519]$} & [0.699] & {$[0.503]^{* * *}$} \\
\hline \multirow{4}{*}{$\begin{array}{c}\text { Economic } \\
\text { circumstances }\end{array}$} & Thriving economy & -8.688 & -7.6 & -7.336 \\
\hline & & {$[0.000]$} & {$[0.000]$} & {$[0.000]$} \\
\hline & Declining economy & 0.385 & -0.439 & -0.242 \\
\hline & & {$[0.343]$} & {$[0.371]$} & {$[0.387]$} \\
\hline \multirow{16}{*}{$\begin{array}{l}\text { Occupational } \\
\text { structure }\end{array}$} & Landowners employing workers & -3.291 & -11.445 & -10.315 \\
\hline & & [4.577] & {$[6.690]^{*}$} & [6.892] \\
\hline & Landowners not employing workers & 5.846 & -0.871 & -1.851 \\
\hline & & [7.291] & [8.223] & [9.167] \\
\hline & Agricultural workers & 4.262 & -1.66 & -0.214 \\
\hline & & {$[2.620]$} & {$[2.778]$} & {$[2.755]$} \\
\hline & Industry workers & 8.563 & 0.749 & 2.526 \\
\hline & & [9.931] & {$[10.686]$} & [12.134] \\
\hline & Other workers & -1.018 & 0.017 & 2.355 \\
\hline & & [2.928] & [2.819] & [2.869] \\
\hline & Artisans & 4.758 & -1.679 & -0.21 \\
\hline & & [2.949] & {$[3.068]$} & {$[3.056]$} \\
\hline & Professionals & 7.479 & -10.447 & -11.957 \\
\hline & & [8.933] & {$[9.289]$} & {$[9.494]$} \\
\hline & Male servants above 20 & -27.193 & -20.463 & -17.457 \\
\hline & & {$[14.065]^{*}$} & {$[15.254]$} & [16.498] \\
\hline \multirow{10}{*}{$\begin{array}{c}\text { Political } \\
\text { circumstances }\end{array}$} & Contested seat & -0.051 & -0.752 & -0.163 \\
\hline & & {$[0.398]$} & {$[0.427]^{*}$} & [0.441] \\
\hline & Constant & -11.025 & -4.024 & -11.652 \\
\hline & & {$[2.342]^{* * *}$} & {$[2.589]$} & {$[2.428]^{* * *}$} \\
\hline & Observations & 111 & 110 & 109 \\
\hline & Non-censored observations & 82 & 86 & 86 \\
\hline & $\lambda$ & -0.042 & -0.153 & -0.188 \\
\hline & & {$[0.157]$} & {$[0.204]$} & [0.129] \\
\hline & Wald $\left(\chi^{2}\right)$ & 615.792 & 35.367 & 465.797 \\
\hline & Prob & 0.000 & 0.004 & 0.000 \\
\hline
\end{tabular}

\footnotetext{
Notes: We do not present results for the Whig vote on 17 December 1831 because we were unable to find a specification which did not entail a specification bias. Standard errors are given in brackets. ${ }^{* *}$ indicates significance at the $1 \%$-level, $* *$ indicates significance at the $5 \%$-level, * indicates significance at the $10 \%$-level.
} 
Table A4. Determinants of the Tories' election and opposition to reform: all the constituencies.

Vote equation of the Tory support for Reform

22 March $1831 \quad 6$ July $1831 \quad 20$ September 1831

17 December 1831

\begin{tabular}{|c|c|c|c|c|c|}
\hline \multirow[t]{7}{*}{ Patronage } & High influence & $\begin{array}{c}0.192 \\
{[0.099]^{*}}\end{array}$ & $\begin{array}{c}0.264 \\
{[0.110]^{* *}}\end{array}$ & $\begin{array}{c}0.43 \\
{[0.094]^{* * *}}\end{array}$ & $\begin{array}{c}0.45 \\
{[0.100]^{* * *}}\end{array}$ \\
\hline & Some influence & 0.113 & 0.23 & 0.445 & 0.462 \\
\hline & & {$[0.093]$} & {$[0.113]^{* *}$} & {$[0.095]^{* * *}$} & {$[0.101]^{* * *}$} \\
\hline & No influence & -0.009 & 0.025 & 0.222 & 0.215 \\
\hline & & {$[0.119]$} & {$[0.145]$} & {$[0.132]^{*}$} & {$[0.140]$} \\
\hline & Treasury borough & 0.366 & 0.3 & 0.433 & 0.364 \\
\hline & & {$[0.147]^{* *}$} & {$[0.156]^{*}$} & {$[0.137]^{* * *}$} & {$[0.160]^{* *}$} \\
\hline \multirow{8}{*}{$\begin{array}{c}\text { Governance } \\
\text { structure }\end{array}$} & Municipal corporation & -0.811 & -0.001 & 0.337 & 0.572 \\
\hline & & {$[0.622]$} & {$[0.348]$} & {$[0.103]^{* * *}$} & {$[0.120]^{* * *}$} \\
\hline & Representative borough & -0.821 & -0.024 & 0.367 & 0.603 \\
\hline & & {$[0.620]$} & {$[0.347]$} & {$[0.112]^{* * *}$} & {$[0.129]^{* * *}$} \\
\hline & University & & & 0.573 & 0.793 \\
\hline & & & & {$[0.302]^{*}$} & {$[0.397]^{* *}$} \\
\hline & County & -0.956 & -0.482 & & \\
\hline & & {$[0.610]$} & {$[0.340]$} & & \\
\hline \multirow{12}{*}{$\begin{array}{c}\text { Franchise } \\
\text { type }\end{array}$} & Burgage franchise & -0.08 & -0.166 & -0.017 & -0.075 \\
\hline & & {$[0.105]$} & {$[0.092]^{*}$} & {$[0.083]$} & {$[0.094]$} \\
\hline & Corporation franchise & 0.078 & -0.061 & 0.057 & 0.017 \\
\hline & & {$[0.112]$} & [0.091] & {$[0.084]$} & {$[0.091]$} \\
\hline & Freeman franchise & -0.018 & -0.127 & -0.006 & 0.001 \\
\hline & & {$[0.082]$} & {$[0.078]$} & {$[0.070]$} & {$[0.083]$} \\
\hline & Scot and lot franchise. & 0.17 & -0.177 & -0.119 & -0.164 \\
\hline & & {$[0.102]^{*}$} & {$[0.092]^{*}$} & {$[0.084]$} & {$[0.094]^{*}$} \\
\hline & Freehold franchise. & 0.097 & -0.621 & -0.15 & -0.403 \\
\hline & & [0.169] & {$[0.308]^{* *}$} & {$[0.278]$} & {$[0.310]$} \\
\hline & Household franchise & -0.562 & & & \\
\hline & & {$[0.468]$} & & & \\
\hline \multirow{14}{*}{$\begin{array}{l}\text { MPs' occupations } \\
\text { X characteristics }\end{array}$} & Army career & 0.052 & -0.091 & -0.057 & -0.012 \\
\hline & & {$[0.081]$} & {$[0.077]$} & {$[0.071]$} & {$[0.077]$} \\
\hline & Financiers & 0.114 & -0.242 & -0.223 & -0.224 \\
\hline & & {$[0.138]$} & {$[0.117]^{* *}$} & {$[0.108]^{* *}$} & {$[0.121]^{*}$} \\
\hline & Dynasty heir & -0.063 & 0.02 & 0.085 & 0.131 \\
\hline & & {$[0.070]$} & {$[0.076]$} & {$[0.068]$} & {$[0.075]^{*}$} \\
\hline & Industrialist & -0.161 & -0.127 & 0.069 & -0.268 \\
\hline & & {$[0.148]$} & {$[0.140]$} & {$[0.134]$} & [0.189] \\
\hline & Jurist & -0.015 & 0.074 & 0.007 & 0.057 \\
\hline & & {$[0.086]$} & {$[0.082]$} & {$[0.074]$} & {$[0.082]$} \\
\hline & Merchant & 0.079 & 0.174 & 0.104 & 0.143 \\
\hline & & {$[0.100]$} & {$[0.105]^{*}$} & [0.099] & {$[0.120]$} \\
\hline & Relatives in Parliament & 0.06 & 0.103 & 0.077 & 0.063 \\
\hline & & {$[0.062]$} & {$[0.057]^{*}$} & {$[0.052]$} & {$[0.057]$} \\
\hline \multirow{6}{*}{$\begin{array}{c}\text { Political } \\
\text { circumstances }\end{array}$} & $\begin{array}{l}\text { Uncontested seat (1800- } \\
1831)\end{array}$ & 0.02 & 0.053 & $-0,069$ & 0 \\
\hline & & {$[0.072]$} & {$[0.063]$} & {$[0.059]$} & {$[0.066]$} \\
\hline & Seats after Reform & & 0.176 & 0.091 & 0.213 \\
\hline & & & {$[0.104]^{*}$} & {$[0.097]$} & {$[0.116]^{*}$} \\
\hline & Constant & 1.534 & 0.543 & 0.134 & -0.408 \\
\hline & & {$[0.585]^{* * *}$} & {$[0.355]$} & {$[0.238]$} & {$[0.314]$} \\
\hline
\end{tabular}

Continuing next page 
Party affiliation equation of the Tories' election in Parliament

22 March $1831 \quad 6$ July $1831 \quad 20$ September 1831

17 December 1831

\begin{tabular}{|c|c|c|c|c|c|}
\hline \multirow[t]{15}{*}{$\begin{array}{c}\text { Occupational } \\
\text { structure }\end{array}$} & $\begin{array}{l}\text { Landowners employing } \\
\text { workers }\end{array}$ & $\begin{array}{c}4.683 \\
{[3.710]}\end{array}$ & $\begin{array}{c}3.155 \\
{[3.501]}\end{array}$ & $\begin{array}{c}2.953 \\
{[3.568]}\end{array}$ & $\begin{array}{c}2.561 \\
{[4.074]}\end{array}$ \\
\hline & $\begin{array}{l}\text { Landowners not } \\
\text { employing workers }\end{array}$ & $\begin{array}{c}3.478 \\
{[3.942]}\end{array}$ & $\begin{array}{c}2.687 \\
{[3.758]}\end{array}$ & $\begin{array}{c}1.162 \\
{[3.832]}\end{array}$ & $\begin{array}{l}-3.047 \\
{[4.381]}\end{array}$ \\
\hline & Agricultural workers & $\begin{array}{c}1.177 \\
{[1.665]}\end{array}$ & $\begin{array}{c}-0.46 \\
{[1.547]}\end{array}$ & $\begin{array}{l}-1.109 \\
{[1.548]}\end{array}$ & $\begin{array}{l}-1.687 \\
{[1.627]}\end{array}$ \\
\hline & Industry workers & $\begin{array}{c}1.44 \\
{[1.648]}\end{array}$ & $\begin{array}{l}-1.365 \\
{[1.556]}\end{array}$ & $\begin{array}{l}-1.854 \\
{[1.553]}\end{array}$ & $\begin{array}{l}-2.318 \\
{[1.618]}\end{array}$ \\
\hline & Other workers & $\begin{array}{c}2.198 \\
{[1.736]}\end{array}$ & $\begin{array}{l}-1.447 \\
{[1.598]}\end{array}$ & $\begin{array}{c}-2.054 \\
{[1.600]}\end{array}$ & $\begin{array}{c}-3.369 \\
{[1.726]^{*}}\end{array}$ \\
\hline & Artisans & $\begin{array}{c}0.368 \\
{[1.710]}\end{array}$ & $\begin{array}{l}-1.182 \\
{[1.578]}\end{array}$ & $\begin{array}{c}-1.882 \\
{[1.582]}\end{array}$ & $\begin{array}{c}-2.196 \\
{[1.646]}\end{array}$ \\
\hline & Professionals & $\begin{array}{c}1.21 \\
{[2.212]}\end{array}$ & $\begin{array}{c}2.613 \\
{[2.745]}\end{array}$ & $\begin{array}{c}2.226 \\
{[2.748]}\end{array}$ & $\begin{array}{c}1.425 \\
{[3.228]}\end{array}$ \\
\hline & Male servants above 20 & $\begin{array}{c}9.707 \\
{[6.094]}\end{array}$ & $\begin{array}{c}-0.383 \\
{[5.860]}\end{array}$ & $\begin{array}{l}-2.683 \\
{[5.989]}\end{array}$ & $\begin{array}{l}-0.066 \\
{[6.275]}\end{array}$ \\
\hline & Male servants below 20 & $\begin{array}{l}-11.027 \\
{[8.545]}\end{array}$ & $\begin{array}{c}3.88 \\
{[8.122]}\end{array}$ & $\begin{array}{c}7.606 \\
{[8.321]}\end{array}$ & $\begin{array}{c}8.886 \\
{[8.666]}\end{array}$ \\
\hline & Female servants & $\begin{array}{c}1.879 \\
{[2.304]}\end{array}$ & $\begin{array}{l}-0.056 \\
{[2.225]}\end{array}$ & $\begin{array}{c}-0.922 \\
{[2.241]}\end{array}$ & $\begin{array}{c}-1.684 \\
{[2.357]}\end{array}$ \\
\hline & Constant & $\begin{array}{l}-1.023 \\
{[1.514]}\end{array}$ & $\begin{array}{c}0.269 \\
{[1.403]}\end{array}$ & $\begin{array}{c}0.848 \\
{[1.403]}\end{array}$ & $\begin{array}{c}1.279 \\
{[1.462]}\end{array}$ \\
\hline & $\begin{array}{l}\text { Observations } \\
\text { Non-censored } \\
\text { observations }\end{array}$ & 480 & $\begin{array}{l}501 \\
280\end{array}$ & $\begin{array}{l}485 \\
280\end{array}$ & $\begin{array}{l}445 \\
280\end{array}$ \\
\hline & $\lambda$ & $\begin{array}{c}-0.193 \\
{[0.242]}\end{array}$ & $\begin{array}{c}-0.25 \\
{[0.168]}\end{array}$ & $\begin{array}{c}-0.217 \\
{[0.149]}\end{array}$ & $\begin{array}{c}-0.177 \\
{[0.154]}\end{array}$ \\
\hline & Wald $\left(\chi^{2}\right)$ & 37.697 & 63.998 & 63.483 & 83.274 \\
\hline & Prob & 0.014 & 0.000 & 0.000 & 0.000 \\
\hline
\end{tabular}

Notes:

- Standard errors are given in brackets.

- *** indicates significance at the $1 \%$-level, $* *$ indicates significance at the $5 \%$-level, * indicates significance at the 10\%-level. 
Table A5. Determinants of the Tories' election and opposition to reform: the disenfranchised boroughs.

\section{Vote equation of the Tory support for Reform}

22 March $1831 \quad 6$ July $1831 \quad 20$ September $1831 \quad 17$ December 1831

\begin{tabular}{|c|c|c|c|c|c|}
\hline \multirow[t]{6}{*}{ Patronage } & High influence & 0.276 & 0.322 & 0.369 & 0.527 \\
\hline & & {$[0.230]$} & {$[0.132]^{* *}$} & {$[0.090]^{* * *}$} & {$[0.076]^{* * *}$} \\
\hline & Some influence & 0.182 & 0.349 & 0.374 & 0.595 \\
\hline & & {$[0.250]$} & {$[0.139]^{* *}$} & {$[0.094]^{* * *}$} & {$[0.081]^{* * *}$} \\
\hline & Treasury borough & -0.19 & 0.5 & 0.409 & 0.565 \\
\hline & & {$[0.343]$} & {$[0.196]^{* *}$} & {$[0.136]^{* * *}$} & {$[0.150]^{* * *}$} \\
\hline \multirow{4}{*}{$\begin{array}{c}\text { Governance } \\
\text { structure }\end{array}$} & Municipal corporation & 0.084 & 0.002 & & \\
\hline & & {$[0.113]$} & [0.059] & & \\
\hline & Representative borough & & & -0.077 & -0.012 \\
\hline & & & & {$[0.040]^{*}$} & {$[0.042]$} \\
\hline \multirow[t]{8}{*}{ Franchise type } & Burgage franchise & -0.042 & -0.097 & 0.025 & 0.052 \\
\hline & & {$[0.160]$} & {$[0.086]$} & {$[0.059]$} & {$[0.061]$} \\
\hline & Corporation franchise & 0.125 & -0.024 & 0.014 & -0.049 \\
\hline & & {$[0.186]$} & {$[0.089]$} & {$[0.064]$} & {$[0.066]$} \\
\hline & Freeman franchise & -0.197 & -0.072 & -0.069 & -0.009 \\
\hline & & {$[0.173]$} & {$[0.085]$} & {$[0.057]$} & {$[0.059]$} \\
\hline & Scot and lot franchise. & 0.066 & -0.092 & -0.048 & -0.093 \\
\hline & & {$[0.162]$} & {$[0.080]$} & {$[0.057]$} & {$[0.053]^{*}$} \\
\hline \multirow{14}{*}{$\begin{array}{l}\text { MPs' occupations } \\
\text { \& characteristics }\end{array}$} & Army career & 0.128 & 0.014 & 0.112 & 0.01 \\
\hline & & {$[0.158]$} & {$[0.083]$} & {$[0.057]^{*}$} & {$[0.061]$} \\
\hline & Financiers & 0.179 & 0.084 & 0.089 & 0.009 \\
\hline & & {$[0.280]$} & {$[0.114]$} & {$[0.078]$} & {$[0.072]$} \\
\hline & Dynasty heir & 0.07 & 0.043 & 0.131 & 0.038 \\
\hline & & {$[0.144]$} & {$[0.077]$} & {$[0.050]^{* * *}$} & {$[0.048]$} \\
\hline & Industrialist & & -0.013 & -0.047 & -0.012 \\
\hline & & & {$[0.139]$} & {$[0.099]$} & {$[0.133]$} \\
\hline & Jurist & -0.053 & 0.12 & 0.063 & 0.004 \\
\hline & & {$[0.138]$} & {$[0.087]$} & {$[0.058]$} & {$[0.055]$} \\
\hline & Merchant & 0.145 & 0.133 & 0.145 & 0.056 \\
\hline & & {$[0.157]$} & {$[0.102]$} & {$[0.073]^{* *}$} & {$[0.068]$} \\
\hline & Relatives in Parliament & -0.189 & 0.093 & -0.017 & 0.036 \\
\hline & & {$[0.099]^{*}$} & {$[0.053]^{*}$} & {$[0.037]$} & {$[0.037]$} \\
\hline \multirow{4}{*}{$\begin{array}{c}\text { Political } \\
\text { circumstances }\end{array}$} & $\begin{array}{l}\text { Uncontested seat } \\
(1800-1831)\end{array}$ & -0.099 & 0.102 & 0.001 & 0.079 \\
\hline & & {$[0.096]$} & {$[0.058]^{*}$} & {$[0.041]$} & [0.049] \\
\hline & Constant & 0.79 & 0.563 & 0.604 & 0.445 \\
\hline & & {$[0.307]^{* *}$} & {$[0.164]^{* * *}$} & {$[0.112]^{* * *}$} & {$[0.098]^{* * *}$} \\
\hline
\end{tabular}

Continuing next page 
Party affiliation equation of the Tories' election in Parliament

22 March $1831 \quad 6$ July $1831 \quad 20$ September $1831 \quad 17$ December 1831

\begin{tabular}{|c|c|c|c|c|c|}
\hline \multirow[t]{6}{*}{ Patronage } & \multirow{2}{*}{ High influence } & -9.562 & -6.884 & -9.7 & -9.047 \\
\hline & & {$[0.365]^{* * *}$} & {$[0.000]$} & {$[0.000]$} & {$[0.000]$} \\
\hline & \multirow[t]{2}{*}{ Some influence } & -9.572 & -7.22 & -9.977 & -9.367 \\
\hline & & {$[0.000]$} & {$[0.360]^{* * *}$} & {$[0.370]^{* * *}$} & {$[0.398]^{* * *}$} \\
\hline & \multirow[t]{2}{*}{ Treasury borough } & -5.162 & -1.318 & -4.016 & -3.323 \\
\hline & & {$[0.000]$} & {$[0.000]$} & {$[0.000]$} & {$[0.000]$} \\
\hline \multirow{4}{*}{$\begin{array}{c}\text { Governance } \\
\text { structure }\end{array}$} & \multirow[t]{2}{*}{ Municipal corporation } & -0.261 & -0.122 & -0.103 & \\
\hline & & {$[0.380]$} & {$[0.358]$} & {$[0.371]$} & \\
\hline & \multirow[t]{2}{*}{ Representative borough } & & & & 0.247 \\
\hline & & & & & {$[0.410]$} \\
\hline \multirow[t]{8}{*}{ Franchise type } & \multirow[t]{2}{*}{ Burgage franchise } & -0.266 & -1.023 & -1.282 & -1.345 \\
\hline & & {$[0.613]$} & {$[0.653]$} & {$[0.713]^{*}$} & {$[0.780]^{*}$} \\
\hline & \multirow[t]{2}{*}{ Corporation franchise } & 0.543 & -0.014 & -0.143 & 0.002 \\
\hline & & {$[0.730]$} & {$[0.728]$} & {$[0.773]$} & {$[0.831]$} \\
\hline & \multirow[t]{2}{*}{ Freeman franchise } & 0.228 & -0.393 & -0.594 & -0.841 \\
\hline & & {$[0.553]$} & {$[0.615]$} & {$[0.672]$} & {$[0.745]$} \\
\hline & \multirow[t]{2}{*}{ Scot and lot franchise. } & -0.453 & -0.48 & -1.01 & -0.897 \\
\hline & & {$[0.561]$} & {$[0.611]$} & {$[0.716]$} & [0.789] \\
\hline \multirow{4}{*}{$\begin{array}{c}\text { Economic } \\
\text { circumstances }\end{array}$} & \multirow[t]{2}{*}{ Thriving economy } & 10.744 & 9.857 & 13.803 & 4.708 \\
\hline & & {$[0.000]$} & {$[0.000]$} & {$[0.000]$} & {$[0.000]$} \\
\hline & \multirow[t]{2}{*}{ Declining economy } & -0.395 & 0.278 & 0.182 & 0.503 \\
\hline & & {$[0.351]$} & {$[0.354]$} & {$[0.359]$} & {$[0.397]$} \\
\hline \multirow{16}{*}{$\begin{array}{l}\text { Occupational } \\
\text { structure }\end{array}$} & \multirow[t]{2}{*}{ Landowners employing workers } & 2.663 & 8.39 & 9.976 & 8.187 \\
\hline & & {$[5.360]$} & {$[6.406]$} & {$[7.155]$} & {$[8.872]$} \\
\hline & \multirow[t]{2}{*}{ Landowners not employing workers } & -0.661 & 0.802 & -0.881 & 0.333 \\
\hline & & {$[7.517]$} & [8.165] & {$[8.460]$} & {$[9.836]$} \\
\hline & \multirow[t]{2}{*}{ Agricultural workers } & -2.85 & 0.267 & 0.313 & -0.103 \\
\hline & & {$[2.593]$} & {$[2.631]$} & {$[2.698]$} & {$[2.683]$} \\
\hline & \multirow[t]{2}{*}{ Industry workers } & -12.309 & -7.513 & -16.163 & -15.275 \\
\hline & & {$[10.971]$} & {$[9.168]$} & [10.697] & {$[11.466]$} \\
\hline & \multirow[t]{2}{*}{ Other workers } & 2.945 & -1.929 & -1.834 & -1.93 \\
\hline & & [2.888] & [2.662] & {$[2.685]$} & {$[2.766]$} \\
\hline & \multirow[t]{2}{*}{ Artisans } & -2.847 & -0.268 & -0.498 & -1.426 \\
\hline & & {$[2.825]$} & {$[2.847]$} & {$[2.910]$} & {$[3.020]$} \\
\hline & Professionals & -6.611 & 9.872 & 8.983 & 7.092 \\
\hline & & [9.387] & {$[9.005]$} & [9.144] & {$[9.884]$} \\
\hline & Male servants above 20 & 28.928 & 18.122 & 15.416 & 29.586 \\
\hline & & {$[14.592]^{* *}$} & [14.797] & [14.682] & {$[18.866]$} \\
\hline Political & Contested seat & 0.171 & 0.612 & 0.833 & 1.101 \\
\hline circumstances & & {$[0.425]$} & {$[0.397]$} & {$[0.451]^{*}$} & {$[0.493]^{* *}$} \\
\hline & Constant & 11.352 & 6.905 & 9.976 & 8.997 \\
\hline & & {$[2.317]^{* * *}$} & {$[2.420]^{* * *}$} & {$[2.500]^{* * *}$} & {$[2.505]^{* * *}$} \\
\hline & Observations & 100 & 108 & 104 & 86 \\
\hline & Non-censored observations & 31 & 27 & 27 & 27 \\
\hline & $\lambda$ & -0.182 & -0.055 & -0.02 & -0.079 \\
\hline & & {$[0.162]$} & {$[0.094]$} & {$[0.061]$} & {$[0.054]$} \\
\hline & Wald $\left(\chi^{2}\right)$ & 773.999 & 460.661 & 778.452 & 693.62 \\
\hline & Prob & 0.000 & 0.000 & 0.000 & 0.000 \\
\hline
\end{tabular}

Notes: Standard errors are given in brackets. $* * *$ indicates significance at the $1 \%$-level, $* *$ indicates significance at the $5 \%$-level, $*$ indicates significance at the $10 \%$-level. 
Figure 1 The occupations of the English and Welsh MPs in the 1830 and 1831 Parliaments.

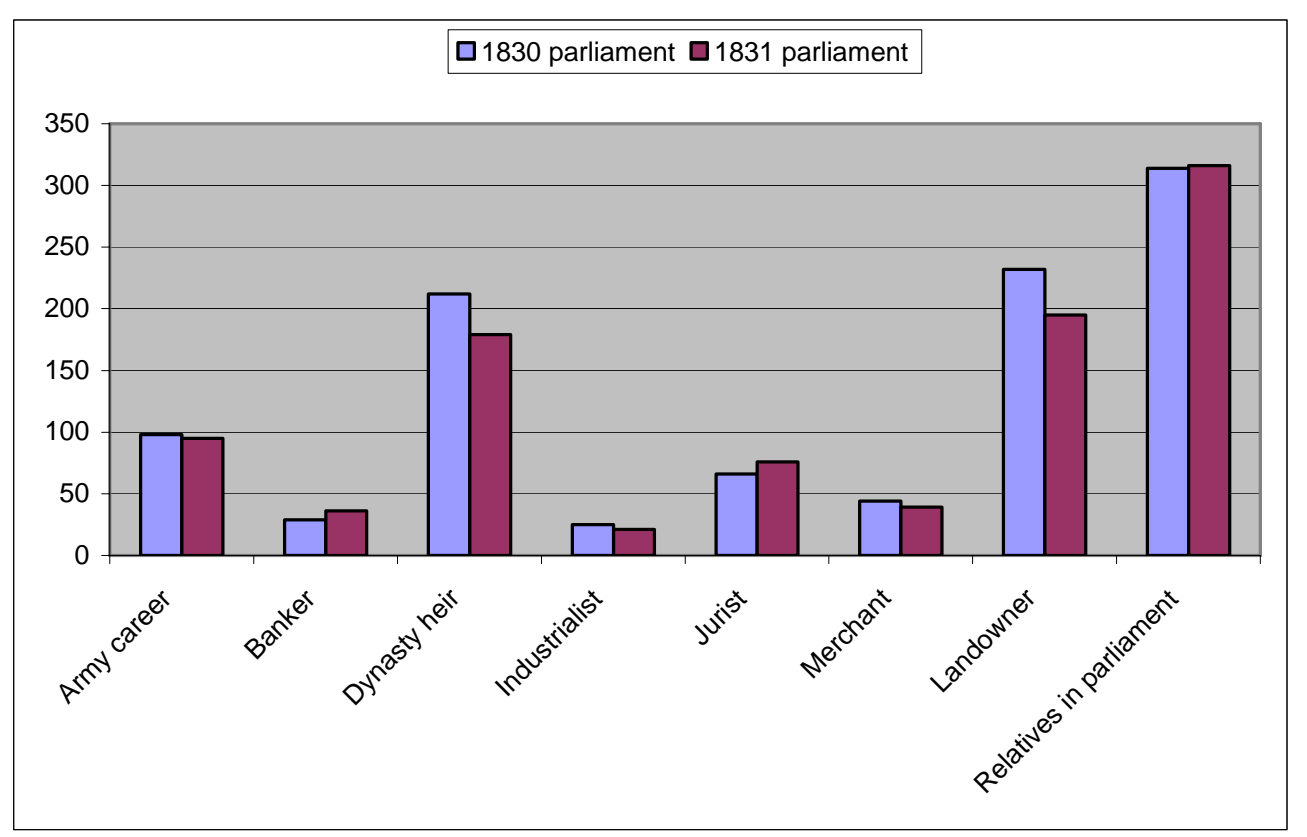

Notes: The different categories are not mutually exclusive and a particular MP can therefore be recorded in more than one category (e.g., army career and landowner).

Sources: Judd (1955), Namier and Brooke (1964), Porrit and Porrit (1903), Stookes Smith (1973), Thorne (1986), and various editions of Dod's Parliamentary companion. 
Figure 2 Number of contested elections between 1802 and 1831 in the English Boroughs.

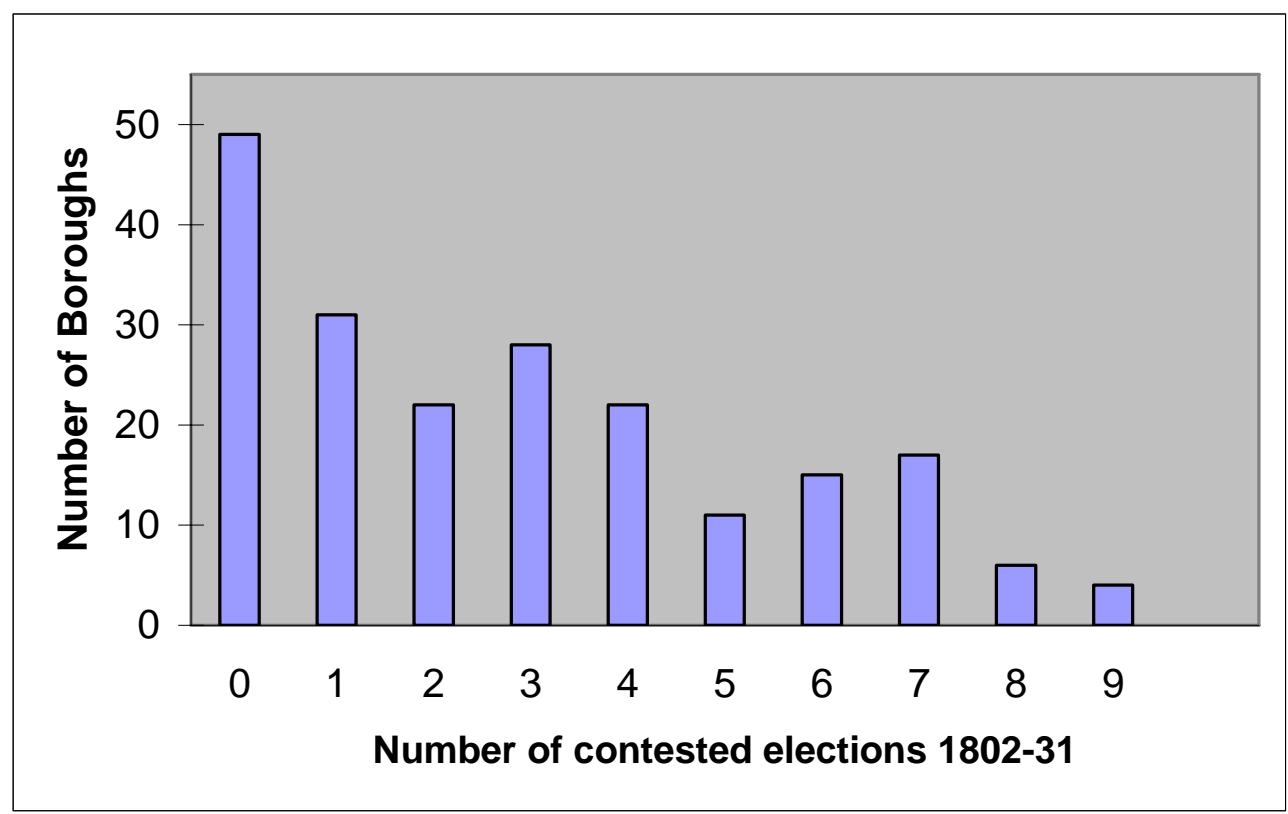

Notes:

The histogram includes Grampound and East Retford which were disenfranchised and had their seats transferred to Yorkshire in 1821 and Bassetlaw in 1826, respectively.

Source: Cannon (1973, Appendix 3). 
Figure 3: Overview of the estimation approach

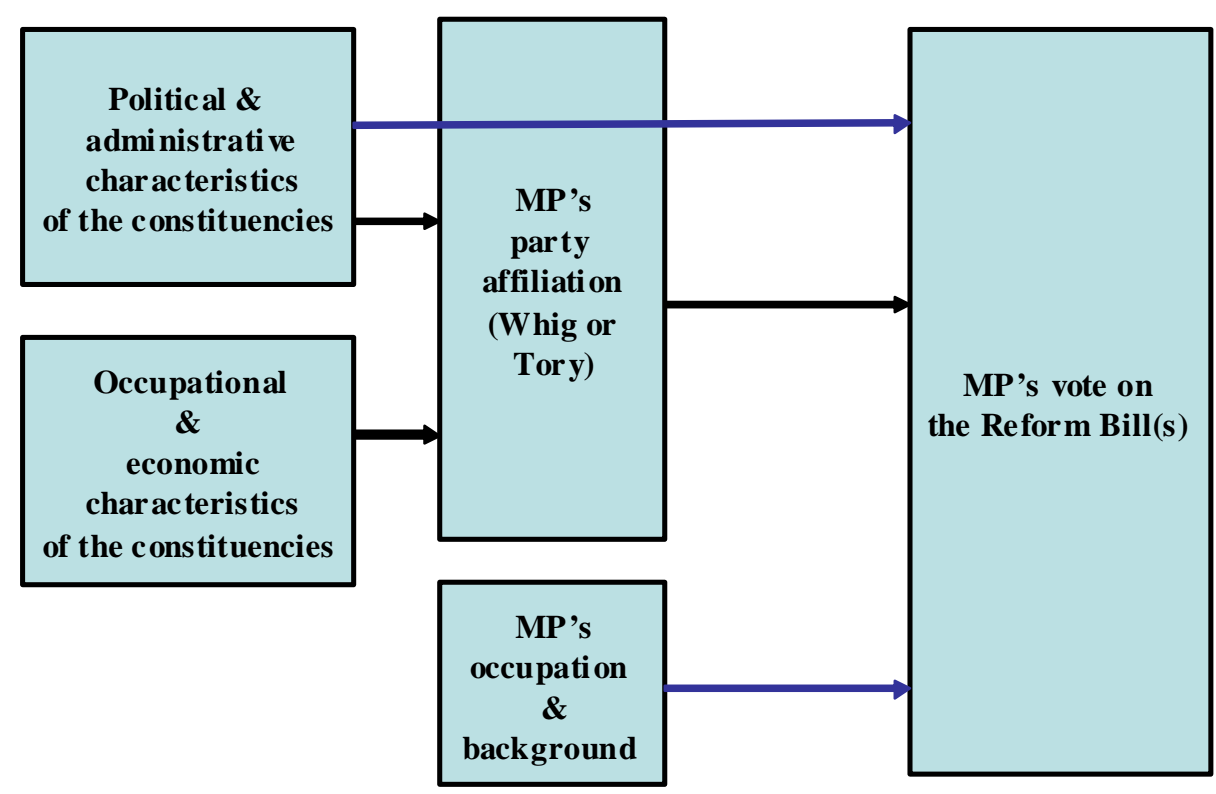

